\title{
Photoproduction of ammonium in the southeastern Beaufort Sea and its biogeochemical implications
}

\author{
H. Xie ${ }^{1}$, S. Bélanger ${ }^{2}$, G. Song ${ }^{1}$, R. Benner ${ }^{3}$, A. Taalba ${ }^{1}$, M. Blais ${ }^{4}$, J.-É. Tremblay ${ }^{4}$, and M. Babin ${ }^{4,5}$ \\ ${ }^{1}$ Institut des Sciences de la Mer de Rimouski, Université du Québec à Rimouski, Rimouski, Québec, G5L 3A1, Canada \\ ${ }^{2}$ Département de Biologie, Chimie et Géographie, Université du Québec à Rimouski, Rimouski, Québec, G5L 3A1, Canada \\ ${ }^{3}$ University of South Carolina, Marine Science Program, Columbia, SC 29208, USA \\ ${ }^{4}$ Département de Biologie, Québec-Océan and Takuvik, Université Laval, Québec, G1V 0A6, Canada \\ ${ }^{5}$ Laboratoire d'Océanographie de Villefranche, CNRS \& Univ. Pierre et Marie Curie, France
}

Correspondence to: H. Xie (huixiang_xie@uqar.qc.ca)

Received: 5 March 2012 - Published in Biogeosciences Discuss.: 13 April 2012

Revised: 26 June 2012 - Accepted: 17 July 2012 - Published: 10 August 2012

\begin{abstract}
Photochemistry of dissolved organic matter (DOM) plays an important role in marine biogeochemical cycles, including the regeneration of inorganic nutrients. DOM photochemistry affects nitrogen cycling by converting biorefractory dissolved organic nitrogen to labile inorganic nitrogen, mainly ammonium $\left(\mathrm{NH}_{4}^{+}\right)$. During the August 2009 Mackenzie Light and Carbon (MALINA) Program, the absorbed photon-based efficiency spectra of $\mathrm{NH}_{4}^{+}$photoproduction (i.e. photoammonification) were determined using water samples from the SE Beaufort Sea, including the Mackenzie River estuary, shelf, and Canada Basin. The photoammonification efficiency decreased with increasing wavelength across the ultraviolet and visible regimes and was higher in offshore waters than in shelf and estuarine waters. The efficiency was positively correlated with the molar nitrogen:carbon ratio of DOM and negatively correlated with the absorption coefficient of chromophoric DOM (CDOM). Combined with collateral measurements of $\mathrm{CO}_{2}$ and $\mathrm{CO}$ photoproduction, this study revealed a stoichiometry of DOM photochemistry with a $\mathrm{CO}_{2}: \mathrm{CO}: \mathrm{NH}_{4}^{+}$molar ratio of $165: 11: 1$ in the estuary, $60: 3: 1$ on the shelf, and $18: 2: 1$ in the Canada Basin. The $\mathrm{NH}_{4}^{+}$efficiency spectra, along with solar photon fluxes, CDOM absorption coefficients and sea ice concentrations, were used to model the monthly surface and depth-integrated photoammonification rates in 2009. The summertime (June-August) rates at the surface reached $6.6 \mathrm{nmoll}^{-1} \mathrm{~d}^{-1}$ on the Mackenzie Shelf and $3.7 \mathrm{nmol}^{-1} \mathrm{~d}^{-1}$ further offshore; the depthintegrated rates were correspondingly $8.8 \mu \mathrm{mol} \mathrm{m}^{-2} \mathrm{~d}^{-1}$ and
\end{abstract}

$11.3 \mu \mathrm{mol} \mathrm{m} \mathrm{m}^{-2} \mathrm{~d}^{-1}$. The offshore depth-integrated rate in August $\left(8.0 \mu \mathrm{mol} \mathrm{m}^{-2} \mathrm{~d}^{-1}\right)$ was comparable to the missing dissolved inorganic nitrogen (DIN) source required to support the observed primary production in the upper 10-m layer of that area. The yearly $\mathrm{NH}_{4}^{+}$photoproduction in the entire study area was estimated to be $1.4 \times 10^{8}$ moles, with $85 \%$ of it being generated in summer when riverine DIN input is low. Photoammonification could mineralize $4 \%$ of the annual dissolved organic nitrogen (DON) exported from the Mackenzie River and provide a DIN source corresponding to $7 \%$ of the riverine DIN discharge and 1400 times the riverine $\mathrm{NH}_{4}^{+}$flux. Under a climate warming-induced ice-free scenario, these quantities could increase correspondingly to $6 \%$, $11 \%$, and 2100 times. Photoammonification is thus a significant nitrogen cycling term and may fuel previously unrecognized autotrophic and heterotrophic production pathways in the surface SE Beaufort Sea.

\section{Introduction}

Photodegradation of dissolved organic nitrogen (DON), a constituent of dissolved organic matter (DOM), produces certain forms of labile nitrogen, mainly ammonium $\left(\mathrm{NH}_{4}^{+}\right)$, thereby contributing to biological production in natural waters (Bushaw et al., 1996). The extent and ecological relevance of $\mathrm{NH}_{4}^{+}$photoproduction (i.e. photoammonification) are, nonetheless, not well constrained because of the large varibility of results obtained by different 
laboratories and from different samples. While many studies observed environmentally relevant rates of photoammonification (e.g. Bushaw et al., 1996; Gao and Zepp, 1998; Vähätalo et al., 2003; Smith and Benner, 2005; Vähätalo and Zepp, 2005; Kitidis et al., 2006; Stedmon et al., 2007; Aarnos et al., 2012), others reported little or no $\mathrm{NH}_{4}^{+}$photoproduction (e.g. Buffam and McGlathery, 2003; Jørgensen et al., 1998; Bertilsson et al., 1999; Wiegner and Seitzinger, 2001) or even photochemical loss of $\mathrm{NH}_{4}^{+}$(Kieber et al., 1997; Koopmans and Bronk, 2002; Vähätalo et al., 2003). These contrasting results have been attributed to variations in DOM's intrinsic properties and prior light exposure history, environmental controls (e.g. pH, iron, oxygen), ambient concentrations of $\mathrm{NH}_{4}^{+}$, and possibly methodological differences as well (Kieber et al., 1997; Gao and Zepp, 1998; Wang et al., 2000; Mopper and Kieber, 2002; Koopmans and Bronk, 2002; Buffam and McGlathery, 2003; Kitidis et al., 2008). The wide range of photoammonification results makes crossregion extrapolation difficult and consequently hampers the evaluation of the overall biogeochemical role of this process.

DON in Arctic rivers is generally more enriched relative to dissolved inorganic nitrogen (DIN) compared to other world rivers (Holmes et al., 2011). The Mackenzie River, the largest North American Arctic river, delivers $2.2 \times 10^{9} \mathrm{~mol} \mathrm{DON} \mathrm{yr}^{-1}$ to the Mackenzie Shelf and the Beaufort Sea (Holmes et al., 2011), but little is known of the transformation and fate of this terrestrial DON pool. Soluble reactive phosphorus in the surface southeastern (SE) Beaufort Sea continues to decline after nitrate is exhausted by the vernal phytoplankton bloom (Simpson et al., 2008; Tremblay et al., 2008). This observation has led to propositions that new sources of bioavailable nitrogen, such as labile riverine DON (e.g. urea) and photochemically produced $\mathrm{NH}_{4}^{+}$, may sustain primary production to some extent after the nitrate depletion (Tremblay et al., 2008).

DOM photochemistry becomes increasingly pertinent to Arctic biogeochemical cycles due to the sensitivity of the Arctic environments to climate warming (Amon, 2004; Bélanger et al., 2006; Osburn et al., 2009; Xie et al., 2009). Rising temperatures lead to sea ice decline, allowing more solar radiation available for DOM photooxidation in the water column. Tank et al. (2011) modeled Pan-Arctic photoammonification rates using published apparent quantum yield (AQY) spectra from the Baltic Sea. Their results demonstrate that photoammonification in the top $10 \mathrm{~m}$ of the Arctic Ocean during the summer melting season can mineralize $5 \%$ of the annual riverine DON input. In view of the potentially large cross-system varibility of photoammonification aforementioned, the validity of applying non-Arctic AQY data to Arctic environments is unclear. The present study, for the first time, measured the AQY spectra of photoammonification in an Arctic marine system, modeled photoammonification rates using the obtained AQY data, and evaluated the biogeochemical implications of this photochemical process in the SE Beaufort Sea.

\section{Methods}

\subsection{Sampling}

Fieldwork was carried out during the Mackenzie Light and Carbon (MALINA) program aboard the CCGS Amundsen in the SE Beaufort Sea from 31 July to 25 August 2009. Sampling stations for photoammonification experiments were distributed along two salinity-gradient transects extending from the mouth of the Mackenzie estuary to the Mackenzie Shelf (Fig. 1). Transect 390, encompassing Sta. 391, 394, 398 , was located off the east channel of the estuary while transect 690, covering Sta. 691, 693, 694, 697, was situated off the west channel. Also visited were two stations in the Canada Basin (Sta. 430 and 640). Twelve-liter standard Niskin bottles, mounted on a conductivity-temperature-depth (CTD) rosette, were used to take waters from the surface $(3.3 \mathrm{~m})$ at Sta. 640 and from $150 \mathrm{~m}$ at Sta. 430 . The latter depth was located within the upper halocline of the Beaufort Sea water column. A small boat, released from the CCGS Amundsen, traversed the two estuarine transects characterized by shallow waters. Surface waters were collected with a clean high-density polyethylene (HDPE) bucket into 101 acid-cleaned HDPE jugs or collapsible bags. Bulk waters in both Niskin bottles and plastic jugs/bags were immediately gravity-filtered through a Whatman Polycap 75 AS filter capsule sequentially containing a $0.2 \mu \mathrm{m}$ glass microfiber filter and a $0.2 \mu \mathrm{m}$ Nylon membrane filter. Prior to sample collection, the capsules were thoroughly rinsed with Nanopure water and sample water to avoid potential contamination. The filtered samples were transferred into acid-cleaned 4-1 clear-glass bottles, stored in darkness at $4{ }^{\circ} \mathrm{C}$, and transported to a land-based laboratory for further treatment within two months of sample collection. Detailed sampling information is given in Table 1 .

\subsection{Irradiations}

Samples brought back from the field were re-filtered with $0.2 \mu \mathrm{m}$ polyethersulfone membrane filters immediately before they were irradiated for determination of the AQY spectra of photoammonification (symbol $\Phi_{\mathrm{NH}_{4}^{+}}$). Each refiltered sample was directly poured into pre-combusted $\left(420^{\circ} \mathrm{C}\right)$ quartz-windowed cylindrical cells (i.d: $3.4 \mathrm{~cm}$; length: $11.4 \mathrm{~cm}$ ). Irradiations followed the procedure reported by Zhang et al. (2006). Briefly, the sample-filled quartz cells were irradiated in a temperature-controlled incubator $\left(4^{\circ} \mathrm{C}\right)$ using a SUNTEST CPS solar simulator equipped with a $1.5-\mathrm{kW}$ xenon lamp. Six spectral treatments employed successive Schott long band-pass glass filters: WG280, WG295, WG320, WG345, GG395, GG435. Spectral irradiance under each filter was measured using an OL-754 spectroradiometer fitted with a 2-inch $(\sim 5 \mathrm{~cm})$ OL IS-270 integrating sphere calibrated with an OL 752$10 \mathrm{E}$ irradiance standard. The irradiance under the WG280 
Table 1. Sampling information and physical and chemical properties of samples for $\Phi_{\mathrm{NH}_{4}^{+}}$determinations.

\begin{tabular}{|c|c|c|c|c|c|c|c|c|c|c|}
\hline Location & Sta. & Date & $\begin{array}{l}\text { Lat. } \\
\left({ }^{\circ} \mathrm{N}\right)\end{array}$ & $\begin{array}{l}\text { Long. } \\
\left({ }^{\circ} \mathrm{W}\right)\end{array}$ & $\begin{array}{r}\text { Sa. } \\
\text { depth }^{\mathrm{a}} \\
(\mathrm{m})\end{array}$ & $\begin{array}{r}\text { Total } \\
\text { depth } \\
(\mathrm{m})\end{array}$ & Salinity & $\begin{array}{r}T \\
\left({ }^{\circ} \mathrm{C}\right)\end{array}$ & $\begin{array}{r}a_{\text {cdom }, 412} \\
\left(\mathrm{~m}^{-1}\right)\end{array}$ & $S_{\mathrm{R}}^{\mathrm{b}}$ \\
\hline \multirow{3}{*}{ Transect 390} & 391 & $16 / 08$ & 70.095 & 133.539 & 0 & 34.6 & 27.82 & 3.2 & 0.11 & 1.458 \\
\hline & 394 & $16 / 08$ & 69.846 & 133.490 & 0 & 11.5 & 21.45 & 8.8 & 0.72 & 1.055 \\
\hline & 398 & $16 / 08$ & 69.534 & 133.424 & 0 & 2.2 & 16.37 & 8.8 & 1.15 & 1.024 \\
\hline \multirow{4}{*}{ Transect 690} & 691 & $13 / 08$ & 69.387 & 137.792 & 0 & 42.6 & 23.61 & 5.2 & 0.37 & 1.149 \\
\hline & 693 & $13 / 08$ & 69.296 & 137.398 & 0 & 32.3 & 15.00 & 8.8 & 1.09 & 0.998 \\
\hline & 694 & $13 / 08$ & 69.251 & 137.202 & 0 & 10.9 & 9.43 & 9.3 & 1.57 & 0.985 \\
\hline & 697 & $13 / 08$ & 69.125 & 136.681 & 0 & 1.0 & 0.15 & 10.3 & 1.98 & 0.992 \\
\hline \multirow{2}{*}{ Offshore } & 430 & $18 / 08$ & 71.184 & 134.748 & 150 & 1300 & 33.13 & -1.4 & 0.17 & 1.527 \\
\hline & 640 & $11 / 08$ & 70.334 & 139.099 & 3.3 & 550 & 21.43 & $2 . .2$ & 0.29 & 1.323 \\
\hline
\end{tabular}

a $0 \mathrm{~m}$ depth indicates bucket samples.

b $S_{\mathrm{R}}=S_{275-295} / S_{350-400}$ where $S_{275-295}$ and $S_{350-400}$ are CDOM's absorption spectral slopes over the wavelength ranges of 275-295 nm and $350-400 \mathrm{~nm}$, respectively (Helms et al., 2008). Spectral slopes were calculated from the model $a_{\mathrm{cdom}, \lambda}=a_{\mathrm{cdom}, \lambda 0} \times \exp \left[S \times\left(\lambda_{0}-\lambda\right)\right]$ where $\lambda_{0}$ is a reference wavelength.

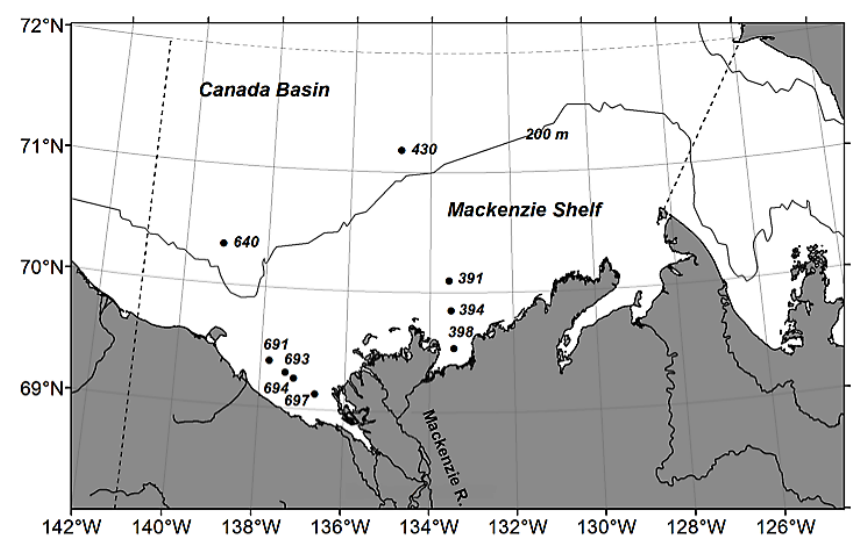

Fig. 1. Map of sampling stations. Solid line denotes the 200-m isobath and dashed line delimits the area for which $\mathrm{NH}_{4}^{+}$photoproduction was modeled.

filter (least filtered light) was $706.3 \mathrm{~W} \mathrm{~m}^{-2}$ in the wavelength range from $280-800 \mathrm{~nm}$. Irradiation lasted from ca. $4-7 \mathrm{~d}$, depending on the sample's initial absorption coefficient. Parallel incubations in darkness showed negligible thermal $\mathrm{NH}_{4}^{+}$ production.

\subsection{Analysis}

Determination of $\mathrm{NH}_{4}^{+}$concentrations followed the fluorometric method of Holmes et al. (1999). Samples were mixed with a working regent containing $o$-phthaldialdehyde (OPA), sodium sulfite, and sodium borate. The addition of sodium sulfide minimizes potential interference from amino acids (Holmes et al., 1999). The sample and working reagent mixture was allowed to stay in the dark for $2.5 \mathrm{~h}$ before its fluorescence was measured with a Trilogy Laboratory Fluorometer (Turner Designs). The procedure was calibrated us- ing freshly prepared ammonium chloride aqueous solutions covering concentrations from 0 to $1.6 \mu \mathrm{moll}^{-1}$. Corrections were made for the sample's background fluorescence and matrix effect caused by substances such as sea salts and DOM (Holmes et al., 1999). The amount of $\mathrm{NH}_{4}^{+}$photochemically produced was taken as the difference between the $\mathrm{NH}_{4}^{+}$concentration in the irradiated sample and that in the parallel dark control.

CDOM absorbance spectra were recorded at room temperature from $250 \mathrm{~nm}$ to $800 \mathrm{~nm}$ at $1 \mathrm{~nm}$ increments using a dual beam UV-visible spectrometer (Perkin Elmer, Lambda 35) fitted with a 5-cm quartz flow cell and referenced to HPLCgrade pure water (Ricca Chemical Company). A baseline correction was applied by subtracting the absorbance value averaged over an interval of $5 \mathrm{~nm}$ around $685 \mathrm{~nm}$ from all the spectral values (Babin et al., 2003). CDOM absorption coefficient (base $e$ ) at wavelength $\lambda, a_{\mathrm{cdom}, \lambda}\left(\mathrm{m}^{-1}\right)$, is calculated as 2.303 times the absorbance divided by the cell's light pathlength in meters. The lower detection limit of $a_{\text {cdom }}$ analysis, defined as three times the standard deviation of five replicate blank measurements using Nanopure water, was $0.02 \mathrm{~m}^{-1}$ over $250 \mathrm{~nm}$ to $700 \mathrm{~nm}$.

Samples for dissolved organic carbon (DOC), total dissolved nitrogen (TDN) and total dissolved amino acids (TDAA) were gravity-filtered (Whatman GF/F filters) directly from Niskin bottles into clean Nalgene HDPE bottles $(60 \mathrm{ml})$ and stored frozen until analysis in the home laboratory (Davis and Benner, 2005). The concentrations of DOC and TDN were measured using high-temperature combustion in a Shimadzu TOC-V analyzer equipped with an inline chemiluminescence nitrogen detector (Davis and Benner, 2005). Dissolved organic nitrogen (DON) was calculated as the difference between TDN and total DIN. The concentrations of nitrate and nitrite were determined 
on freshly collected samples using an Autoanalyzer 3 (Bran + Luebbe) with colorimetric methods adapted from Grasshoff et al. (1999). Total dissolved amino acids (TDAA) were measured as OPA derivatives using an Agilent 1100 high performance liquid chromatography system with a fluorescence detector (Davis and Benner, 2005). Salinity (except bucket samples) and temperature were recorded using a SeaBird 911+ CTD profiler. Salinity for bucket samples was determined using an AutoSal 8400B salinometer (precision: \pm 0.002 ).

\subsection{Retrieval of ammonium AQY}

The spectral AQY of $\mathrm{NH}_{4}^{+}, \Phi_{\mathrm{NH}_{4}^{+}, \lambda}$, is defined as the number of moles of $\mathrm{NH}_{4}^{+}$produced per mole of photons absorbed by CDOM at wavelength $\lambda$. The number of photons absorbed by $\mathrm{CDOM}$ at $\lambda, Q_{\mathrm{a}, \lambda}$ (mol photons $\left.\mathrm{s}^{-1} \mathrm{~nm}^{-1}\right)$, was calculated according to Eq. (1) (Hu et al., 2002):

$$
Q_{\mathrm{a}, \lambda}=A \times Q_{0, \lambda} \times \frac{a_{\mathrm{cdom}, \lambda}}{a_{\mathrm{cdom}+\mathrm{w}, \lambda}}\left[1-\exp \left(-a_{\mathrm{cdom}+\mathrm{w}, \lambda} \times L\right)\right]
$$

where $A\left(\mathrm{~m}^{-2}\right)$ and $L(\mathrm{~m})$ denote, respectively, the cross section and pathlength of the irradiation cell, $Q_{0, \lambda}$ the photon flux just below the front window of the cell, and $a_{\mathrm{cdom}+\mathrm{w}, \lambda}$ the sum of absorption by $\operatorname{CDOM}\left(a_{\mathrm{cdom}, \lambda}\right)$ and water $\left(a_{\mathrm{w}, \lambda}\right)$. Values of $a_{\mathrm{w}, \lambda}$ were taken from Pope and Fry (1997) and Buiteveld et al. (1994) for the visible and UV domains, respectively.

$\Phi_{\mathrm{NH}_{4}^{+}, \lambda}$ was derived with an iterative curve-fit protocol previously established to model AQYs of $\mathrm{CO}$ and $\mathrm{CO}_{2}$ photoproduction under polychromatic light (Johannessen and Miller, 2001; Zhang et al., 2006). Ziolkowski and Miller (2007) confirmed that this multi-spectral approach agrees with the conventional monochromatic method for retrieving CO AQY spectra. Briefly, this method assumed an appropriate mathematical form with unknown parameters to express the change of $\Phi_{\mathrm{NH}_{4}^{+}}$as a function of wavelength. The amount of $\mathrm{NH}_{4}^{+}$produced in an irradiation cell over the exposure time could then be predicted as the product of the assumed $\Phi_{\mathrm{NH}_{4}^{+}}$function and the number of photons absorbed by CDOM integrated over the $280-500 \mathrm{~nm}$ wavelength range, assuming negligible $\mathrm{NH}_{4}^{+}$production at wavelengths $>500 \mathrm{~nm}$ (Sect. 3.2). The optimum values of the unknown parameters in the assumed $\Phi_{\mathrm{NH}_{4}^{+}}$function were obtained by varying these parameters from initial estimates until the minimum difference between the measured and predicted production is achieved. The following quasiexponential form was adopted to fit the data:

$\Phi_{\mathrm{NH}_{4}^{+}, \lambda}=m_{1} \times \exp \left(\frac{m_{2}}{\lambda+m_{3}}\right)$

where $m_{1}, m_{2}$, and $m_{3}$ are fitting parameters. This function generally performs better, particularly in the long UV and visible wavelengths, than the simple 2-parameter exponential form (Supplement Table SM1) (Bélanger et al., 2006;
Zhang et al., 2006; Xie et al., 2009). It is similar to the twopart exponential equation adopted by several previous studies to characterize the multiple exponential behavior of $\mathrm{CO}$ AQY spectra (Zafiriou et al., 2003; Stubbins et al., 2006; Ziolkowski and Miller, 2007). $\mathrm{NH}_{4}^{+}$production rates predicted from the retrieved $\Phi_{\mathrm{NH}_{4}^{+}}$spectra agreed well with measured rates, with $r^{2}$ ranging from 0.976-0.997 (Table 2).

\subsection{Blank, reproducibility and linearity}

The blank, reproducibility, and linearity of $\mathrm{NH}_{4}^{+}$photoproduction were tested only with radiation under cutoff filter WG280 and on a limited number of samples due to constrains on irradiation time and sample volumes. To determine the blank, six quartz cells were filled with HPLCgrade pure water (Ricca Chemical Company) and irradiated for $9.8 \mathrm{~d}$. This gave an $\mathrm{NH}_{4}^{+}$photoproduction rate of $-0.08 \pm 2.6 \mathrm{nmol}^{-1} \mathrm{~d}^{-1}$ (mean \pm 2 s.d., $95 \%$ confidence interval; all uncertainty expressions hereinafter are based on the $95 \%$ confidence interval). The reproducibility was evaluated on the sample from Sta. 430 (irradiation time: $11.5 \mathrm{~d}$ ), arriving at a rate of $17.9 \pm 3.6 \mathrm{nmoll}^{-1} \mathrm{~d}^{-1}$ or $20 \%(n=$ $6)$. The $10 \%$ relative standard deviation should represent or approach the uncertainties for $\mathrm{NH}_{4}^{+}$photoproduction under shortwave cutoff irradiations described above (WG280, WG295, WG320) but likely to underestimate the uncertainties under longwave cutoff irradiations (WG345, GG395, GG435) where $\mathrm{NH}_{4}^{+}$productions were substantially lower (Sect. 3.2). A time-course irradiation was performed on a filtration-sterilized Mackenzie River water sample collected from the east channel of the Mackenzie Delta slightly upstream of Inuvik, the Northwest Territory of Canada, on 11 June 2009. $\mathrm{NH}_{4}^{+}$concentration increased linearly within the first $6.74 \mathrm{~d}$, close to the longest irradiation times for $\Phi_{\mathrm{NH}_{4}^{+}}$ determination (Sect. 2.2). Photoammonification continued thereafter at a lower rate (Fig. 2), consistent with previous studies (e.g. Bushaw et al., 1996; Vähätalo and Zepp, 2005). Similar kinetic patterns are expected for samples collected from the two estuarine transects, which were strongly influenced by the Mackenzie runoff. The kinetic behavior for offshore Sta. 640 and 430 was, however, less certain, since the riverine impact there was weaker.

\section{Results and discussion}

\subsection{Physicochemical properties}

The salinity, temperature and optical properties of samples are summarized in Table 1. Salinity along transect 690 monotonically increased from 0.15 at Sta. 697 to 23.61 at Sta. 691. Transect 390 covered a much narrower salinity range: 16.37 at Sta. 398 to 27.82 at Sta. 391. Owing to dilution by sea ice meltwater and possibly meteoric water as well, surface salinity at Sta. 640 (21.43) in the Canada Basin was considerably 
Table 2. Fitted parameters for Eq. (2) and AQY of photoammonification at $330 \mathrm{~nm}$ (unit: $\mathrm{mol} \mathrm{NH}_{4}^{+}\left(\mathrm{mol}\right.$ quanta) ${ }^{-1}$ ).

\begin{tabular}{lrrrrrr}
\hline Location & Station & $m_{1} \times 10^{9}$ & $m_{2}$ & $m_{3}$ & $r^{2 \mathrm{a}}$ & $\Phi_{\mathrm{NH}_{4}^{+}, 330} \times 10^{6 \mathrm{~b}}$ \\
\hline \multirow{2}{*}{ Transect } & 391 & 384 & 179 & -234 & 0.995 & $2.5 \pm 0.5$ \\
390 & 394 & 185 & 205 & -230 & 0.976 & $1.4 \pm 0.3$ \\
& 398 & 146 & 238 & -230 & 0.986 & $1.6 \pm 0.3$ \\
\hline \multirow{3}{*}{ Transect } & 691 & 439 & 143 & -234 & 0.997 & $2.0 \pm 0.4$ \\
690 & 693 & 245 & 145 & -237 & 0.990 & $1.2 \pm 0.2$ \\
& 694 & 171 & 172 & -233 & 0.984 & $1.0 \pm 0.2$ \\
& 697 & 4.11 & 1010 & -150 & 0.997 & $1.1 \pm 0.2$ \\
\multirow{2}{*}{ Offshore } & 430 & 303 & 223 & -227 & 0.990 & $2.6 \pm 0.5$ \\
& 640 & 532 & 118 & -237 & 0.988 & $1.9 \pm 0.4$ \\
\hline
\end{tabular}

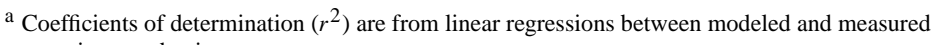
ammonium production rates.

b $95 \%$ confidence interval calculated from the combined varibility of factors used to determine $\Phi_{\mathrm{NH}_{4}^{+}, \lambda}$ (i.e. measured $\mathrm{NH}_{4}^{+}$photoproduction rate, $Q_{0, \lambda}$ and $a_{\mathrm{cdom}, \lambda}$ in Eq. 1).

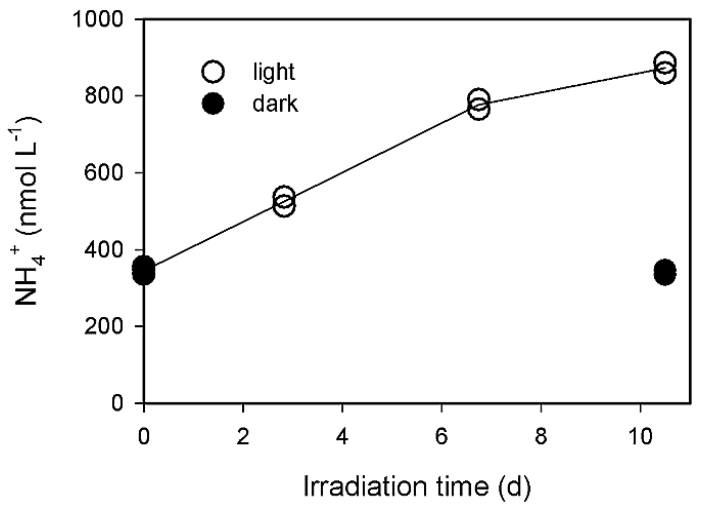

Fig. 2. $\mathrm{NH}_{4}^{+}$concentration as a function of irradiation time for the sample collected in June 2009 from the mid-channel of the Mackenzie River off Inuvik, the Northwest Territory of Canada. The sample was exposed to full-spectrum irradiation. Line connects mean of duplicates at each irradiation time point.

lower than those at Sta. 391 and 691 on the Mackenzie Shelf. Sea surface temperature (SST) trended inversely to salinity, decreasing from inshore to offshore. SST ranged from $5.2^{\circ} \mathrm{C}$ to $10.3{ }^{\circ} \mathrm{C}$ along transect 690 and from $3.2{ }^{\circ} \mathrm{C}$ to $8.8^{\circ} \mathrm{C}$ along transect 390, with the lowest SST occurring at Sta. 640 $\left(2.2{ }^{\circ} \mathrm{C}\right) . \mathrm{CDOM}$ absorption coefficients (as examplified by $\left.a_{\text {cdom,412 }}\right)$ were negatively correlated with salinity for both transects excluding Sta. 697 (Fig. 3a), indicating conservative mixing behavior across the land-ocean transitional zone. However, $a_{\text {cdom }, 412}$ at the innermost Sta. 697 was $20 \%$ lower $\left(1.98 \mathrm{~m}^{-1}\right.$ vs. $\left.2.38 \mathrm{~m}^{-1}\right)$ than expected from the linear fit for the outer section of transect 690, suggesting CDOM input slightly downstream of Sta. 697. The process responsible for this input was unclear but could be linked to episodic sediment resuspensions due to shallow water depths there. The CDOM mixing line of transect 390 was consistently above that of transect 690 within the encountered salinity range (Fig. 3a), implying a larger CDOM end member in the east channel of the Mackenzie River. Sta. 640's $a_{\mathrm{cdom}, 412}$ lay below the mixing lines of the two transects, since sea ice meltwater was depleted with CDOM (Matsuoka et al., 2012). On the contrary, Sta. 430's subsurface sample (150 m deep) exhibited $a_{\mathrm{cdom}, 412}$ far greater than inferred from the two mixing lines (Fig. 3a). This observation is consistent with the finding that the upper halocline water of the Beaufort Sea, originating from the Pacific winter water mass formation, entrains organic-rich freshwater during its northward transit along the Alaska coast (Matsuoka et al., 2012).

The spectral slope ratio, $S_{\mathrm{R}}$, as defined in Table 1, has been used as an indicator of CDOM molecular weight with a lower $S_{\mathrm{R}}$, implying high molecular weight typical of a stronger terrestrial CDOM signature (Helms et al., 2008). The $S_{\mathrm{R}}$ vs. salinity relationship for the combined data of transects 390 and 690 could be well described by a 3-parameter exponential function (Fig. $3 \mathrm{~b}$ ). $S_{\mathrm{R}}$ displayed little variation at salinity $<21.5$ but increased rapidly with salinity at values $>23$. Station 640's $S_{\mathrm{R}}$ was well above the trendline for the two transects, whereas Sta. 430's was far below it. Therefore, CDOM was of more marine character at Sta. 640 but of more terrestrial nature at Sta. 430 than expected from their salinities. If $S_{\mathrm{R}}$ was plotted against $a_{\mathrm{cdom}, 412}$, all data points closely followed the mixing line constructed from Sta. 697 and Sta. 430 as end members, (Fig. 3c), suggesting that CDOM was a more conservative tracer than salinity for describing the dynamics of $S_{\mathrm{R}}$. $S_{\mathrm{R}}$ remained quite constant at $a_{\mathrm{cdom}, 412}>0.7 \mathrm{~m}^{-1}$ and rose quickly with $a_{\mathrm{cdom}, 412}$ at values $<0.4 \mathrm{~m}^{-1}$. Both the $S_{\mathrm{R}}$-salinity and $S_{\mathrm{R}}-a_{\mathrm{cdom}, 412}$ plots thus categorize the sampling stations into two groups. Group 1, covering Sta. 394, 398, 693, 694 and 697 with $S_{\mathrm{R}}$ ranging from 0.992 to 1.055 , possessed CDOM of essentially terristrial origin; and Group 2, comprising Sta. 391, 430, 640 and 
A)

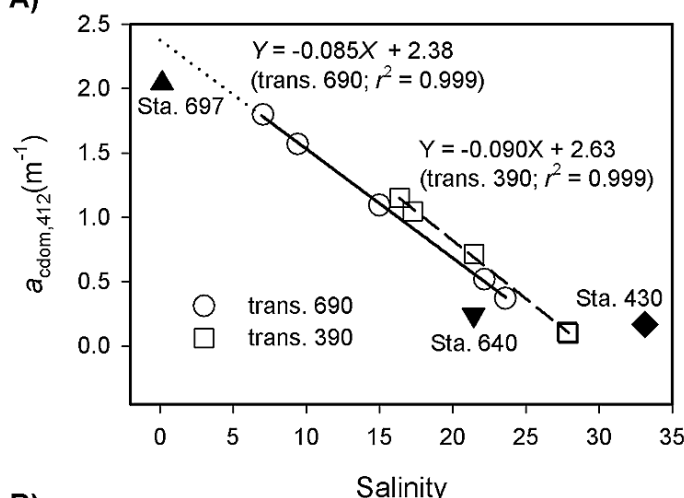

B)

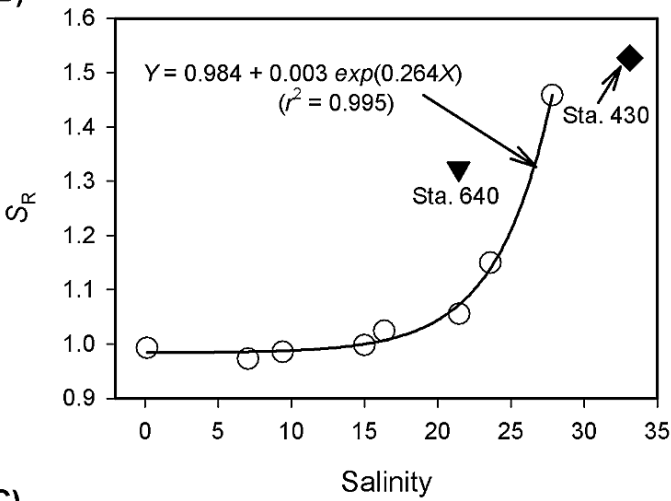

C)

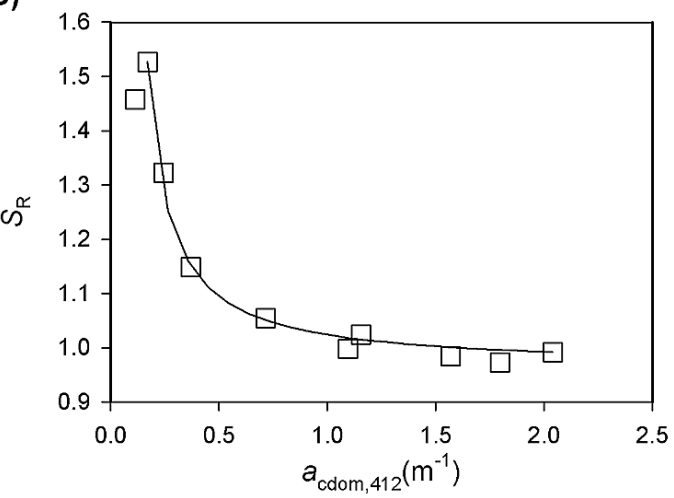

Fig. 3. Plots of CDOM absorption coefficient at $412 \mathrm{~nm}$ vs. salinity (A) and plots of spectral slope ratio vs. salinity (B) and $a_{\text {cdom,412 }}(\mathbf{C})$. Panel (A) solid and dashed lines are best fits for transects 690 (excluding Sta. 698) and 390, respectively; dotted line is the extrapolation from the solid line. Panel (B) circles represent data combining transects 390 and 690 (excluding Sta. 430 and Sta. 640); line is best fit of circles. Panel (C) line is the conservative mixing line of $S_{\mathrm{R}}$ vs. $a_{\mathrm{cdom}, 412}$ using Sta. 697 as the riverine end member and Sta. 430 as the marine end member.

691 with $S_{\mathrm{R}}$ ranging from $1.149-1.527$, carried CDOM having a significant marine signature. It should be pointed out that photobleaching also increases $S_{\mathrm{R}}$ (Helms et al., 2008). The largely conservative behaviors of $a_{\text {cdom }}$ (Fig. 3a) and $S_{\mathrm{R}}$ (Fig. 3c), however, suggested that photoleaching should not be the dominant factor controlling $S_{\mathrm{R}}$ in the study area. The lack of substantial photobleaching observed in the present study is consistent with the conclusion of a previous photobleaching modeling study for the Mackenzie Shelf area (Osburn et al., 2009).

\subsection{Indicators of ammonium photoproduction}

Figure 4 shows typical coastal and offshore CDOM absorption spectra and the corresponding $\mathrm{NH}_{4}^{+}$photoproduction rates as a function of cutoff wavelength observed in laboratory irradiations. $\mathrm{NH}_{4}^{+}$production rate decreased rapidly with increasing cutoff wavelength with the production under cutoff filter GG435 (50\% transmittance cutoff at $430 \mathrm{~nm}$ ) being $<8 \%$ of the production under cutoff filter WG280 ( $50 \%$ transmittance cutoff at $268 \mathrm{~nm}$ ). High-CDOM samples consistently gave high $\mathrm{NH}_{4}^{+}$production rates, particularly at short cutoff wavelengths. $\mathrm{NH}_{4}^{+}$production decreased approximately linearly with salinity $\left(r^{2}=0.718, n=9, p<0.01\right)$, excluding the June Mackenzie River water sample. The latter showed a much higher $\mathrm{NH}_{4}^{+}$production rate compared to the freshest sample (Sta. 697, salinity 0.15) that was taken in August (Fig. 5a). However, such inconsistency was essentially absent for the relationship of $\mathrm{NH}_{4}^{+}$production to CDOM (Fig. 5b). The two exhibited a good positive, linear correlation $\left(r^{2}=0.945, n=10, p<0.01\right)$. $\mathrm{NH}_{4}^{+}$production also increased linearly with DON $\left(r^{2}=0.912, n=7\right.$, $p<0.01$ ) and TDAA (Fig. 5c and d). For TDAA, Sta. 691 was an exception whose $\mathrm{NH}_{4}^{+}$production was much lower than expected from the highly elevated TDAA level. Consequently, $\mathrm{NH}_{4}^{+}$production was only weakly related to TDAA $\left(r^{2}=0.492, n=7, p>0.05\right)$. Hence amino acids, of which $>90 \%$ were combined forms (R. Benner, unpublished data, 2012), were probably not the predominant precursors of $\mathrm{NH}_{4}^{+}$photoproduction. Tarr et al. (2001) reached a similar conclusion based on a mechanism study on photoammonification of natural organic matter. Our supposition is also in line with the finding that the concentrations of TDAA in the Broad River, South Carolina, are controlled primarily by microbial utilization rather than photodegradation (Benner and Kaiser, 2011).

\subsection{AQYs of ammonium photoproduction}

Fitted parameters for Eq. (2) are shown in Table 2 and $\Phi_{\mathrm{NH}_{4}^{+}}$spectra representative of coastal and offshore waters are displayed in Fig. 6a. Offshore waters (Sta. 430 and 640) had higher $\Phi_{\mathrm{NH}_{4}^{+}}$values than did coastal waters (Sta. 693 and 697) at wavelengths $>300 \mathrm{~nm}$. $\Phi_{\mathrm{NH}_{4}^{+}}$ for Sta. 697 decreased with wavelength more quickly than $\Phi_{\mathrm{NH}_{4}^{+}}$for other stations. At $330 \mathrm{~nm}$, the mean $\Phi_{\mathrm{NH}_{4}^{+}}$ for Group 2 stations $\left(2.2 \times 10^{-6} \pm 0.6 \times 10^{-6} \mathrm{~mol} \mathrm{NH}_{4}^{+}\right.$ (mol quanta $)^{-1}$ ) was twice that for Group 1 stations $\left(1.2 \times 10^{-6} \pm 0.4 \times 10^{-6} \mathrm{~mol} \mathrm{NH}_{4}^{+}\right.$(mol quanta) $\left.{ }^{-1}\right)$. Compared to previously reported $\mathrm{NH}_{4}^{+} \mathrm{AQY}$ data, our values 


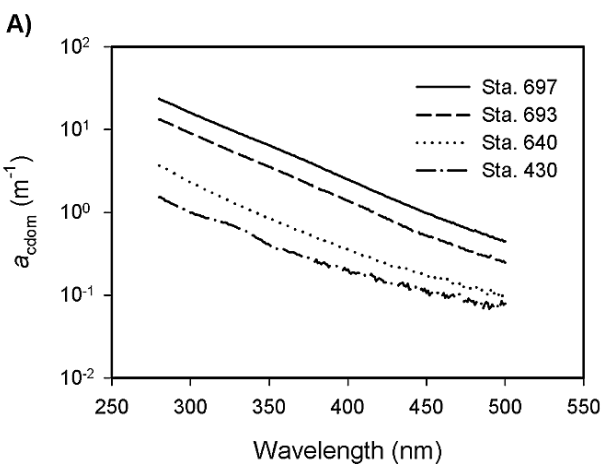

B)

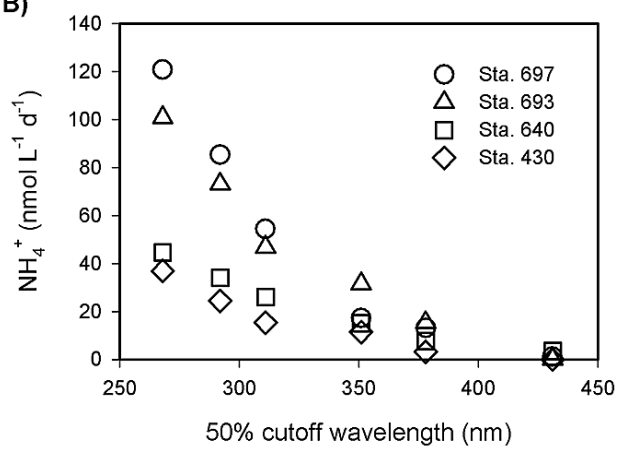

Fig. 4. Typical CDOM absorption spectra (A) and their corresponding $\mathrm{NH}_{4}^{+}$photoproduction rates as a function of cutoff wavelength observed from laboratory irradiations $(\mathbf{B})$.

are generally lower in the UV wavelengths and similar or higher in the visible wavelengths (Fig. 6a). The overall range of AQY at $330 \mathrm{~nm}$ in the present study was from $1.0 \times 10^{-6} \mathrm{~mol} \mathrm{NH}_{4}^{+}$(mol quanta) ${ }^{-1}$ to $2.6 \times 10^{-6} \mathrm{molNH}_{4}^{+}$(mol quanta) ${ }^{-1}$, which are far below those observed by Vähätalo and Zepp (2005) (range: $11 \times 10^{-6}-61 \times 10^{-6} \mathrm{~mol} \mathrm{NH}_{4}^{+}\left(\mathrm{mol}\right.$ quanta) $\left.{ }^{-1}\right)$ and Stedmon et al. (2007) (range: $27 \times 10^{-6}-144 \times 10^{-6} \mathrm{~mol} \mathrm{NH}_{4}^{+}$ (mol quanta) ${ }^{-1}$ ) but close to the lower end of those reported by Aarnos et al. (2012) (range: $3.5 \times 10^{-6}$ $11 \times 10^{-6} \mathrm{~mol} \mathrm{NH}_{4}^{+}$(mol quanta) ${ }^{-1}$ ). To the best of our knowledge, these are the only published photoammonification AQYs and they were all obtained from the Baltic Sea, with the data of Aarnos et al. (2012) covering larger spatiotemporal scales. Our lower AQY values, particularly in the most photochemically active UV wavelengths, may indicate a lower photoreactivity of DON in our sampling area, reflecting the fact that the water discharged into the Baltic Sea is much more strongly impacted by human activity (e.g. agriculture) than the water flowing into the Beaufort Sea. However, the lower irradiation temperature adopted in the present study, $4{ }^{\circ} \mathrm{C}$ vs. near room temperature in the studies by Vähätalo and Zepp (2005) and Stedmon et al. (2007), should also have decreased the AQY values, since DOM photochemical reactions, such as CO photoproduction (Zhang et al., 2006), can be temperature dependent. Aarnos
A)
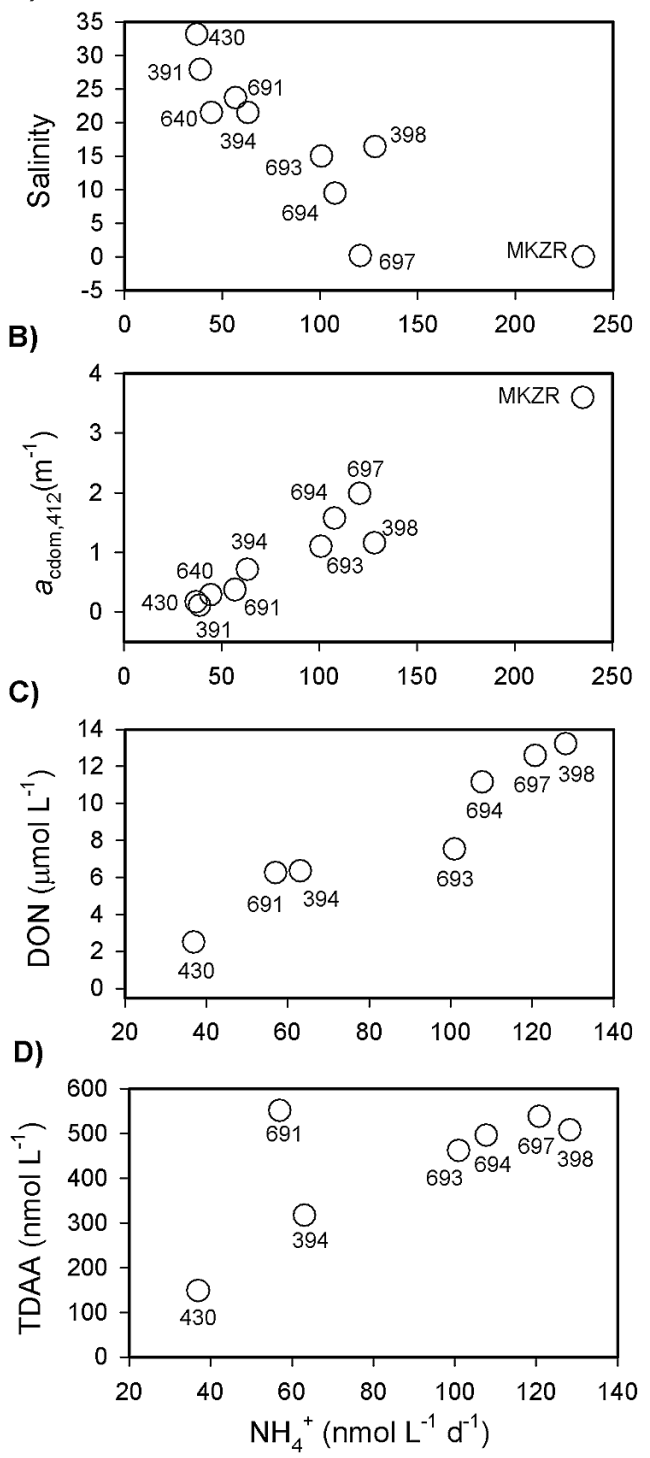

Fig. 5. Plots of ammonium photoproduction rate vs. salinity (A), CDOM absorption coefficient (B), dissolved organic nitrogen (C), and total dissolved amino acids (D). Data labels represent station numbers and MKZR denotes the June 2009 sample collected in the Mackenzie River near Inuvik (see Sect. 2.5). No DON and TDAA data are available for the MKZR station. $\mathrm{NH}_{4}^{+}$photoproduction rates were determined under cutoff filter WG280.

et al. (2012) used a similarly low irradiation temperature $\left(5^{\circ} \mathrm{C}\right)$, which may partly explain the much smaller difference between their results and ours. Hence, photoammonification is plausibly a strong temperature-dependent process. Note that our lower AQYs could also be partly caused by the relatively long exposure periods (4-7 d), since $\Phi_{\mathrm{NH}_{4}^{+}}$can decrease with increasing doses of absorbed photons if photoammonificable DON in a sample is depleted during irradiation (Bushaw et al., 1996; Kitidis et al., 2008; Vähätalo and Zepp, 

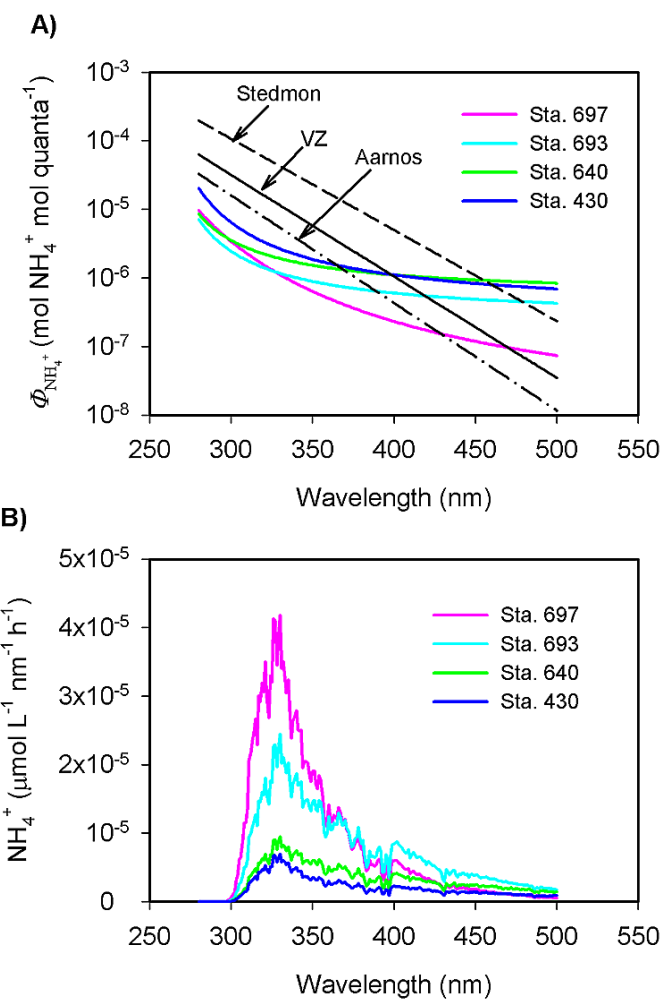

Fig. 6. Examples of apparent quantum yield (A) and action (B) spectra of photoammonification. Also shown in panel (A) are AQY spectra from the literature. VZ stands for Vähätalo and Zepp (2005) (station LL12), Stedmon for Stedmon et al. (2007) (station Kotka), and Aarnos for Aarnos et al. (2012) (station III-Gulf of Finland).

2005). The linear relationship between photoammonification and irradiation time (Fig. 2; at irradiation times $<7$ d), however, implied that the photoammonificable DON was not the limiting factor, at least for the riverine DOM-dominated samples. Because the offshore samples were subjected to longer exposures but had higher $\Phi_{\mathrm{NH}_{4}^{+}}$compared with the nearshore samples, substrates did not appear to be exhausted in the offshore samples either. The linear correlation between the photoammonification rate under the WG280 cutoff filter and $a_{\text {cdom }}$ (Fig. 5a) further corroborated that substrate-limitation was unimportant, since samples under the WG280 cutoff filter received the highest UV irradiance and CDOM absorbed very different amounts of photons among different samples. Use of aged samples (see Sect. 2.1) might lead to lower $\Phi_{\mathrm{NH}_{4}^{+}}$values as well if loss of photoammonificable DON occurred during sample storage. Nevertheless, $a_{\mathrm{cdom}}$ changed little over the two-month storage period (Supplement Fig. SM1), which, combined with the linear relationship between the photoammonification rate and $a_{\text {cdom }}$, suggested that the storage effect was minimal.

To evaluate the spectral dependence of photoammonification in natural waters, action spectra were calculated as $Q_{\lambda} \times$ $a_{\mathrm{cdom}, \lambda} \times \Phi_{\mathrm{NH}_{4}^{+}, \lambda}$, where $Q_{\lambda}$ (mol photons $\mathrm{m}^{-2} \mathrm{~s}^{-1} \mathrm{~nm}^{-1}$ ) is the surface spectral solar photon fluxes at $70^{\circ} \mathrm{N}, 133^{\circ} \mathrm{W}$ at 14:00 local time on 1 July, simulated using the SMARTS model (Simple Model of the Atmospheric Radiative Transfer of Sunshine; Gueymard, 2001) under mid-summer Arctic atmospheric and cloudless conditions with an ozone column burden of 330 Dobson Units. The $\mathrm{NH}_{4}^{+}$action spectra (Fig. 6b), characterized by a non-Gaussian shape with a long tail in the visible, are like those of $\mathrm{CO}$ and $\mathrm{CO}_{2}$ (Zhang et al., 2006; White et al., 2010). They demonstrate that UVB radiation $(280-320 \mathrm{~nm})$ contributed 8-18\%, UVA (320-400 nm) $58-71 \%$, and visible $(400-500 \mathrm{~nm}) 11-33 \%$ of the surface $\mathrm{NH}_{4}^{+}$photoproduction integrated over the full active wavelength range $(280-500 \mathrm{~nm})$. The dominant role of UVA observed in the present study is consistent with previous results (Bushaw et al., 1996; Vähätalo and Zepp, 2005; Stedmon et al., 2007; Aarnos et al., 2012). Notably, the offshore sites (Sta. 430 and 640) held the lowest contributions from UVB $(10 \%$ and $8 \%)$ and the highest contributions from the visible (31\% and 33\%) while the most nearshore sites (Sta. 398 and 697) behaved conversely, $13 \%$ and $18 \%$ from UVB and $21 \%$ and $11 \%$ from the visible. This spectral contribution pattern is consistent with the $\Phi_{\mathrm{NH}_{4}^{+}}$spectra of the nearshore samples being steeper than those of the offshore samples (Fig. 6a). Notwithstanding the widely differing values and/or spectral shapes of $a_{\text {cdom }}$ and $\Phi_{\mathrm{NH}_{4}^{+}}$(Figs. 4a and 6a), all action spectra converge at the same wavelength $(330 \mathrm{~nm})$ giving the maximum $\mathrm{NH}_{4}^{+}$production rates (Fig. $6 \mathrm{~b}$ ). This wavelength is similar to the peak production wavelengths exhibited by $\mathrm{CO}$ and $\mathrm{CO}_{2}$ action spectra (Zhang et al., 2006; White et al., 2010).

Previous studies have revealed that CO AQYs are linearly and positively correlated with CDOM absorption coefficients (Xie et al, 2009; Stubbins et al., 2011). Here we also tested the relationship between $\Phi_{\mathrm{NH}_{4}^{+}}$and $a_{\text {cdom }}$ and found the two variables to be inversely correlated. Based on the residual sum of squares (RSS) and the adjusted coefficient of determination (adjusted $r^{2}$ ) of the regression between the predicted and determined $\Phi_{\mathrm{NH}_{4}^{+}}$, the relationship between $\Phi_{\mathrm{NH}_{4}^{+}}$ and $a_{\text {cdom }}$ switched from being linear over $421-500 \mathrm{~nm}$ to a 2-parameter single exponential over $350-420 \mathrm{~nm}$ to a 3parameter single exponential over 290-349 (Fig. 7). It should be noted that the $\Phi_{\mathrm{NH}_{4}^{+}}$versus $a_{\text {cdom }}$ patterns identified here did not necessarily imply a causative relationship between the two parameters. $\Phi_{\mathrm{NH}_{4}^{+}}$was more likely controlled by the chemical characteristics of CDOM than by CDOM abundance. As low-CDOM samples contained a larger component of CDOM of marine origin (Sect. 3.1), the inverse correspondence between $\Phi_{\mathrm{NH}_{4}^{+}}$and $a_{\text {cdom }}$ points to marine CDOM being more efficient than its terrestrial counterpart at photoammonification. $\mathrm{NH}_{4}^{+}$photoproduction thus contrasts with $\mathrm{CO}$ photoproduction, which is more efficient with terrestrial than marine CDOM (Zafiriou et al., 2003; Xie et al., 2009; Stubbins et al., 2011). Since $a_{\text {cdom }}$ was anti-correlated with 


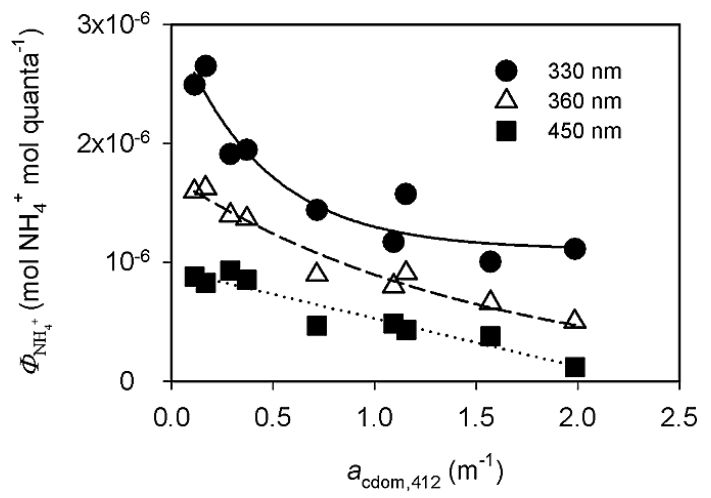

Fig. 7. Regression analysis between $\mathrm{NH}_{4}^{+}$apparent quantum yields and CDOM absorption coefficients at $412 \mathrm{~nm}$ at three selected wavelengths, $330 \mathrm{~nm}, 360 \mathrm{~nm}$, and $450 \mathrm{~nm}$. Data were fitted to the equations of $Y=1.1 \times 10^{-6}+1.9 \times 10^{-6} \exp (-2.3 X)$ at $330 \mathrm{~nm}$ (solid line; $\left.r^{2}=0.914\right), Y=1.7 \times 10^{-6} \exp (-0.65 X)$ at $360 \mathrm{~nm}$ (dashed line; $r^{2}=0.960$ ), and $Y=9.3 \times 10^{-7}-4.1 X$ (dotted line; $\left.r^{2}=0.912\right)$.

salinity (Fig. 3), it is not surprising that $\Phi_{\mathrm{NH}_{4}^{+}}$increased with salinity (data not shown), excluding the ice meltwaterinfluenced Sta. 640. Aarnos et al. (2012) identified a similar $\Phi_{\mathrm{NH}_{4}^{+}}$-salinity relationship for the Baltic Sea. A closer examination further revealed that $\Phi_{\mathrm{NH}_{4}^{+}}$co-varied with the molar DON : DOC ratio (Fig. 8), the latter increasing linearly with salinity $\left(r^{2}=0.718, n=7, p<0.02\right)$. The higher $\Phi_{\mathrm{NH}_{4}^{+}}$in offshore waters was thus likely linked to the higher quality of DOM in terms of the relative DON abundance.

\subsection{Modeling ammonium photoproduction}

The photoammonification rate at the surface $(0 \mathrm{~m})$, $P_{\mathrm{NH}_{4}^{+}, 0}\left(\mathrm{~mol} \mathrm{NH}_{4}^{+} \mathrm{m}^{-3} \mathrm{~d}^{-1}\right)$, were calculated using Eq. (3):

$P_{\mathrm{NH}_{4}^{+}, 0}=\int_{290}^{500} Q_{0-, \lambda} \times a_{\mathrm{cdom}, \lambda} \times \Phi_{\mathrm{NH}_{4}^{+}, \lambda} \times d \lambda$

$Q_{0-, \lambda}$ denotes the scalar photon flux just beneath the surface (mol photons $\mathrm{m}^{-2} \mathrm{~d}^{-1} \mathrm{~nm}^{-1}$ ), which was estimated as 1.3 times the downwelling photon flux, $Q_{d 0-, \lambda}$ (Gordon, 1989). Assuming negligible backscattering of light to the atmosphere and vertical homogeneity of $\Phi_{\mathrm{NH}_{4}^{+}}$and light-absorbing constituents in the photic layer, the water column or depth-integrated photoammonification rate, $P_{\mathrm{NH}_{4}^{+}, \text {col }}\left(\mathrm{mol} \mathrm{NH}_{4}^{+} \mathrm{m}^{-2} \mathrm{~d}^{-1}\right)$, is given by Eq. (4):

$P_{\mathrm{NH}_{4}^{+}, \text {col }}=\int_{290}^{500} Q_{d 0-, \lambda} \times \frac{a_{\mathrm{cdom}, \lambda}}{a_{\mathrm{t}, \lambda}} \times \Phi_{\mathrm{NH}_{4}^{+}, \lambda} \times d \lambda$.

Here $a_{\mathrm{t}, \lambda}$ denotes the total absorption coefficient $\left(\mathrm{m}^{-1}\right)$, i.e. the sum of the absorption coefficients of CDOM, particles, and seawater. The study area was divided into two

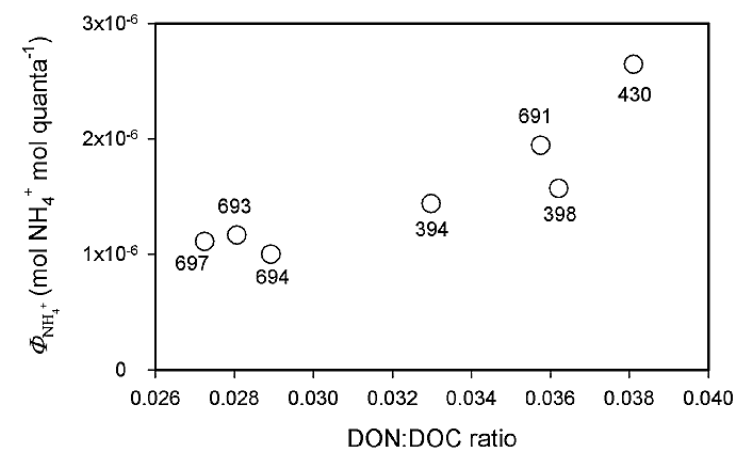

Fig. 8. Plot of $\mathrm{NH}_{4}^{+}$apparent quantum yield at $330 \mathrm{~nm}$ vs. the molar DON : DOC ratio. Data labels represent station numbers.

sub-regions: the Mackenzie Shelf with total water depths $<200 \mathrm{~m}$ and the Canada Basin farther offshore (Fig. 1). Monthly $a_{\mathrm{cdom}, \lambda}: a_{\mathrm{t}, \lambda}$ ratios and $a_{\mathrm{t}, 412}$ values were retrieved from the ocean color data of the Sea Wide field-of-view Sensor (SeaWiFS) using the empirical algorithm of Bélanger et al. (2008) and the quasi-analytical algorithm of Lee et al. (2002; IOCCG, 2006), respectively. Then $a_{\mathrm{cdom}, 412}$ was calculated as the product of the $a_{\mathrm{cdom}, \lambda}: a_{\mathrm{t}, \lambda}$ ratio and $a_{\mathrm{t}, 412}$ (Bélanger, 2006). $\Phi_{\mathrm{NH}_{4}^{+}, \lambda}$ was fitted to $a_{\mathrm{cdom}, 412}$ based on the wavelength-specific relationships shown in Fig. 7. Fitting results are presented as online supplemental materials (Supplement Table SM2). Daily $Q_{d 0-, \lambda}$ values were computed at 5-nm intervals using pre-computed look-up-table (LUT) generated using the Santa Barbara DISORT Atmospheric Radiative Transfer (SBDART) software tool (Ricchiazzi et al., 1998). The LUT inputs were the solar zenith angle, total ozone concentration, cloud fraction over the pixel, and cloud optical thickness. The last three parameters, derived from satellite data following the method developed by Zhang et al. (2004) to produce global radiative flux data (FD), were obtained from the International Satellite Cloud Climatology Project (ISCCP) website. The ISCCP-FD data were distributed on a $280-\mathrm{km}$ equal-area grid at 3-h intervals for dates between January 1983 and December 2009. This method was previously validated against in situ irradiance measurements (Xie et al., 2009). Daily surface ice concentration data derived from passive microwaves sensors (SSMI) were provided by the US National Snow and Ice Data Center. Monthly and annual $P_{\mathrm{NH}_{4}^{+}, 0}$ and $P_{\mathrm{NH}_{4}^{+} \text {,col were calculated at spatial }}$ resolutions of one L3 SeaWiFS pixel $(9.28 \mathrm{~km} \times 9.28 \mathrm{~km})$.

Table 3 summarizes $P_{\mathrm{NH}_{4}^{+}, 0}$ and $P_{\mathrm{NH}_{4}^{+}, \text {col }}$, along with other relevant parameters for each sub-region. Seasonally, $P_{\mathrm{NH}_{4}^{+} \text {,col }}$ reached maximum in June on the Mackenzie Shelf $\left(10.7 \mu \mathrm{mol} \mathrm{m} \mathrm{m}^{-2} \mathrm{~d}^{-1}\right)$ and in July in the Canada Basin $\left(13.3 \mu \mathrm{mol} \mathrm{m} \mathrm{m}^{-2} \mathrm{~d}^{-1}\right)$, and decreased gradually toward successively earlier and later months of the year. As the June or July $a_{\text {cdom }}: a_{\mathrm{t}}$ ratio was not highest on a yearly basis, solar insolation was the dominant factor controlling 
Table 3. Modeled monthly ammonium photoproduction rates in open waters of the SE Beaufort Sea in 2009, along with open-water areas, ocean color-derived $a_{\mathrm{cdom}, 412}: a_{\mathrm{t}, 412}$ ratios and $a_{\mathrm{cdom}, 412}$, and downwelling UV photon fluxes. Open-water areas excluded those where no ocean-color data were available. Lack of ocean color data also left out October and November. December to March were omitted due to nearly complete ice cover. MS stands for Mackenzie Shelf and CB for Canada Basin.

\begin{tabular}{|c|c|c|c|c|c|c|c|}
\hline Region & Apr & May & Jun & Jul & Aug & Sep & Annual \\
\hline \multicolumn{8}{|c|}{ Open-water areas $\left(\mathrm{km}^{2}\right)$} \\
\hline MS & 1015 & 5674 & 44406 & 62667 & 65667 & 74652 & 54889 \\
\hline $\mathrm{CB}$ & 92 & 5784 & 37394 & 57391 & 73939 & 78561 & 50182 \\
\hline \multicolumn{8}{|c|}{$a_{\mathrm{cdom}, 412} / a_{\mathrm{t}, 412}$} \\
\hline MS & 0.56 & 0.56 & 0.59 & 0.60 & 0.75 & 0.70 & 0.66 \\
\hline $\mathrm{CB}$ & 0.54 & 0.66 & 0.68 & 0.75 & 0.76 & 0.77 & 0.75 \\
\hline \multicolumn{8}{|c|}{$a_{\text {cdom }, 412}\left(\mathrm{~m}^{-1}\right)$} \\
\hline MS & 0.09 & 0.19 & 0.21 & 0.26 & 0.57 & 0.41 & 0.38 \\
\hline $\mathrm{CB}$ & 0.05 & 0.17 & 0.10 & 0.19 & 0.12 & 0.15 & 0.14 \\
\hline \multicolumn{8}{|c|}{ UV photon flux $\left(290-400 \mathrm{~nm}, \mathrm{~mol} \mathrm{~m}^{-2} \mathrm{~d}^{-1}\right)$} \\
\hline MS & 1.3 & 2.2 & 3.4 & 3.2 & 2.0 & 1.0 & 2.2 \\
\hline $\mathrm{CB}$ & 1.2 & 1.9 & 3.3 & 3.1 & 1.9 & 0.9 & 2.0 \\
\hline \multicolumn{8}{|c|}{ Surface ammonium photoproduction $\left(P_{\mathrm{NH}_{4}^{+}, 0}, \mathrm{nmoll}^{-1} \mathrm{~d}^{-1}\right)^{*}$} \\
\hline MS & $1.5 \pm 0.7$ & $4.3 \pm 2.0$ & $6.4 \pm 3.0$ & $6.8 \pm 3.2$ & $8.3 \pm 3.9$ & $3.8 \pm 1.8$ & $4.6 \pm 2.2$ \\
\hline $\mathrm{CB}$ & $1.1 \pm 0.5$ & $3.0 \pm 1.4$ & $3.6 \pm 1.7$ & $5.2 \pm 2.4$ & $2.2 \pm 1.0$ & $1.4 \pm 0.7$ & $2.7 \pm 1.3$ \\
\hline \multicolumn{8}{|c|}{ Depth-integrated ammonium photoproduction $\left(P_{\mathrm{NH}_{4}^{+}, \mathrm{col}}, \mu \mathrm{mol} \mathrm{m}{ }^{-2} \mathrm{~d}^{-1}\right)^{*}$} \\
\hline MS & $4.7 \pm 1.4$ & $6.5 \pm 1.9$ & $10.7 \pm 3.1$ & $10.5 \pm 3.0$ & $7.2 \pm 2.1$ & $4.4 \pm 1.3$ & $6.2 \pm 1.8$ \\
\hline $\mathrm{CB}$ & $5.0 \pm 1.5$ & $7.4 \pm 2.1$ & $12.5 \pm 3.6$ & $13.3 \pm 3.9$ & $8.0 \pm 2.3$ & $4.2 \pm 1.2$ & $7.4 \pm 2.1$ \\
\hline \multicolumn{8}{|c|}{ Area-integrated ammonium photoproduction $\left(\sum P_{\mathrm{NH}_{4}^{+}, \text {col }}, 10^{5} \text { moles }\right)^{*}$} \\
\hline MS & $1.4 \pm 0.4$ & $11.4 \pm 3.3$ & $143 \pm 41$ & $203 \pm 59$ & $168 \pm 49$ & $99 \pm 29$ & $625 \pm 181$ \\
\hline $\mathrm{CB}$ & $0.14 \pm 0.04$ & $13.3 \pm 3.9$ & $141 \pm 41$ & $236 \pm 68$ & $185 \pm 54$ & $100 \pm 29$ & $675 \pm 196$ \\
\hline Sum & $1.5 \pm 0.4$ & $24.7 \pm 7.2$ & $284 \pm 82$ & $439 \pm 127$ & $353 \pm 103$ & $199 \pm 58$ & $1300 \pm 377$ \\
\hline
\end{tabular}

$P_{\mathrm{NH}_{4}^{+} \text {,col }}$ in both sub-regions. The seasonality of $P_{\mathrm{NH}_{4}^{+}, 0}$ in the Canada Basin parelleled that of $P_{\mathrm{NH}_{4}^{+} \text {, col }}$, attaining a peak value of $5.2 \mathrm{nmol}^{-1} \mathrm{~d}^{-1}$ in July. The maximum $P_{\mathrm{NH}_{4}^{+}, 0}$ on the shelf, however, occurred in August $\left(8.3 \mathrm{nmoll}^{-1} \mathrm{~d}^{-1}\right)$, two months later than the maximum $P_{\mathrm{NH}_{4}^{+} \text {,col }}$, due to the much higher $a_{\text {cdom }}$ in August as compared to June $\left(a_{\text {cdom, } 412}: 0.57 \mathrm{~m}^{-1}\right.$ vs. $\left.0.21 \mathrm{~m}^{-1}\right)$. This pattern could be attributed to the characteristic CDOM dynamics occurring on the Mackenzie Shelf revealed by satellitederived ocean color data (Bélanger et al., 2006). CDOM from freshwater runoff is held close to the shore by sea ice in spring and extends offshore after sea ice breakup in early summer. Consequently, riverine CDOM is more extensively spread over the shelf in August, about two to three months after the peak discharge of the Mackenzie River, resulting in a larger amount of photochemically active solar energy being absorbed near the sea surface. Spatially, $P_{\mathrm{NH}_{4}^{+}, 0}$ was higher on the shelf than in the basin as a result of higher shelf $a_{\text {cdom }}$ (Table 3 ). $P_{\mathrm{NH}_{4}^{+} \text {, col }}$, nevertheless, exhibited a pattern opposite to that of $P_{\mathrm{NH}_{4}^{+}, 0}$, since both the $a_{\text {cdom }}: a_{\mathrm{t}}$ ratio and $\Phi_{\mathrm{NH}_{4}^{+}}$were higher offshore. Finer distributional patterns of $P_{\mathrm{NH}_{4}^{+}, 0}$ and $P_{\mathrm{NH}_{4}^{+}, \mathrm{col}}$ can be gleaned from their contour maps (Fig. 9). Consistent with decreasing $a_{\text {cdom }}$ seaward, $P_{\mathrm{NH}_{4}^{+}, 0}$ steadily declined from the shore to the open ocean. $P_{\mathrm{NH}_{4}^{+} \text {, col }}$ in the basin displayed relatively small vari-

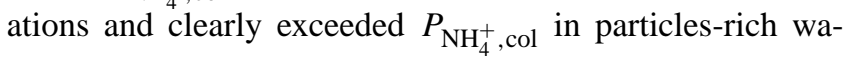
ters close to the land. There existed a narrow strip of high $P_{\mathrm{NH}_{4}^{+} \text {, col }}$, particularly west of $135^{\circ} \mathrm{W}$, at the offshore fringe of the river plumes where light absoroption was strongly dominated by CDOM. This phenomenon is in accordance 

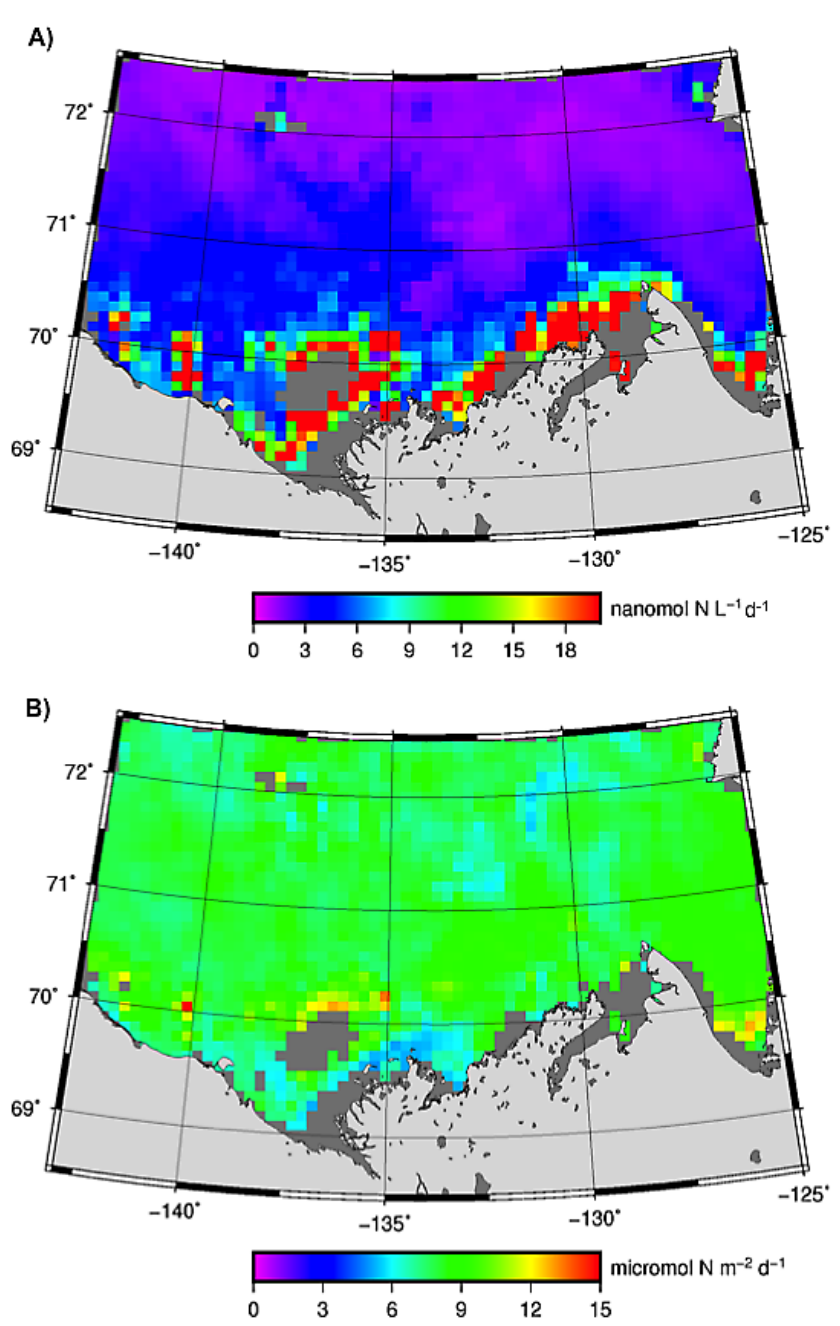

Fig. 9. Contour maps of modeled $\mathrm{NH}_{4}^{+}$photoproduction rates at the sea surface $\left(P_{\mathrm{NH}_{4}^{+}, 0}, \mathbf{A}\right)$ and in the entire water column $\left(P_{\mathrm{NH}_{4}^{+}, \text {col }}\right.$, B) in August 2009. Grey color denotes lack of satellite ocean color data due to sea ice, persistent cloud cover or extreme turbidity.

with highly elevated $a_{\text {cdom }}: a_{\mathrm{t}}$ ratios, reaching up to $90 \%$ at $412 \mathrm{~nm}$, in a similarly confined zone observed by Bélanger et al. (2008; their Fig. 9). Note that the onshore-offshore patterns of photoammonification rates revealed in the present study were relatively consistent across a fairly broad expanse of the Beaufort Sea. It is, therefore, worthwhile to verify in future studies if similar patterns also exist in other Arctic seas. At the same time, caution should be exercised to apply our photoammonification rates to other coastal waters of the Arctic Ocean, given that the chemical characteristics (e.g. DON and DOC concentrations, particle loads) of the Mackenzie River are quite different from those large Siberian rivers (Dittmar and Kattner, 2003; Holmes et al., 2011).

Vähätalo and Zepp (2005) modeled the summer-season (May-August) photoammonification rates in the Baltic Sea using a simplified approach. They yielded surface produc- tion rates spanning from $31 \mathrm{nmoll}^{-1} \mathrm{~d}^{-1}$ to $331 \mathrm{nmol}^{-1} \mathrm{~d}^{-1}$ (mean: $143 \mathrm{nmol} \mathrm{l}^{-1} \mathrm{~d}^{-1}$ ) and water column production rates from $16 \mu \mathrm{mol} \mathrm{m}^{-2} \mathrm{~d}^{-1}$ to $102 \mu \mathrm{mol} \mathrm{m}^{-2} \mathrm{~d}^{-1}$ (mean: $53 \mu \mathrm{mol} \mathrm{m}{ }^{-2} \mathrm{~d}^{-1}$ ), which are substantailly higher than our summertime (June-August) surface (range: 2.9$8.1 \mathrm{nmol}^{-1} \mathrm{~d}^{-1}$; mean: $5.5 \mathrm{nmol}^{-1} \mathrm{~d}^{-1}$ ) and water column (range: $7.1-12.9 \mu \mathrm{mol} \mathrm{m}^{-2} \mathrm{~d}^{-1}$; mean: $10.0 \mu \mathrm{mol} \mathrm{m}^{-2} \mathrm{~d}^{-1}$ ) production rates. Main elements contributing to this difference are the much smaller $\Phi_{\mathrm{NH}_{4}^{+}}$in the UV wavelengths (Sect. 3.3) and relatively lower solar insolation in the SE Beaufort Sea as compared to those in Baltic Sea. The assumption made by Vähätalo and Zepp (2005) that all light in the water column is absorbed by CDOM (i.e. $a_{\text {cdom }}$, $\left.\lambda: a_{\mathrm{t}, \lambda}=1\right)$ should also somewhat bias their rates upward (see Bélanger et al., 2008). In a more recent Baltic Sea survey, Aarnos et al. (2012) reported much lower summertime production rates ranging from $\sim 6$ to $22 \mu \mathrm{mol} \mathrm{m}{ }^{-2} \mathrm{~d}^{-1}$ (mean: $\sim 13 \mu \mathrm{mol} \mathrm{m}{ }^{-2} \mathrm{~d}^{-1}$ ), which are close to our rate for the SE Beaufort Sea. Tank et al. (2011) modeled the PanArctic photoammonification rates using AQY spectra reproted in the literature and arrived at a summertime (JuneAugust) rate of $\sim 33 \mu \mathrm{mol} \mathrm{m} \mathrm{m}^{-2} \mathrm{~d}^{-1}$, with a range across an order of magnitude, depending on the choice of the AQY spectrum. The summertime rates we obtained for the SE Beaufort Sea are within the lower end of their range.

Area-integrated $\mathrm{NH}_{4}^{+}$photoproduction, $\sum P_{\mathrm{NH}_{4}^{+}, \text {col }}$, displayed similar seasonal and regional patterns to those of $P_{\mathrm{NH}_{4}^{+} \text {,col }}$, reaching a maximum in July and ascending from nearshore to offshore (Table 3). April was an exception, when $\sum P_{\mathrm{NH}_{4}^{+} \text {, col }}$ was much lower in the basin than on the shelf $\left(0.14 \times 10^{5}\right.$ vs. $1.4 \times 10^{5}$ moles $)$ due obviously to the much smaller ice-free surface area in the former region in early spring ( 92 vs. $1015 \mathrm{~km}^{2}$ ). The total annual $\mathrm{NH}_{4}^{+}$photoproduction in the entire study area was estimated to be $1.3 \times 10^{8}$ moles, of which $85 \%\left(1.1 \times 10^{8}\right.$ moles $)$ was contributed by the summer season (June-August). Note that this assessment omitted the open water areas where no satellite-based ocean color data were available. The underestimation stemming from this omission was calculated to be $1.2 \times 10^{7}$ moles, assuming a constant $a_{\mathrm{cdom}, 412}: a_{\mathrm{t}, 412}$ ratio of 0.70 and a constant $a_{\mathrm{t}, 412}$ of $0.15 \mathrm{~m}^{-1}$ based on a previous study by Bélanger et al. (2006). The total annual $\mathrm{NH}_{4}^{+}$production thus arrived at $1.4 \times 10^{8}$ moles. October and November were exlcuded also due to lack of satellite ocean color data. Under a global warming-induced totally ice-free scenario, the $\mathrm{NH}_{4}^{+}$yielded from photoammonification could amount to $2.1 \times 10^{8} \mathrm{~mol} \mathrm{yr}^{-1}$. Note that our estimate does not include $\mathrm{NH}_{4}^{+}$photoproduction from particulate organic matter (POM), which has recently been confirmed by several studies using algal detritus (Mayer et al., 2009; H. Xie, unpublished data, 2012). As POM absorbed roughly $30 \%$ of the solar radiation on an annual basis (Table 3), including particulate $\mathrm{NH}_{4}^{+}$photoproduction could increase the above 
estimates by $30 \%$ as well, i.e. $1.8 \times 10^{8} \mathrm{~mol} \mathrm{yr}^{-1}$ under actual ice-cover conditions or $2.7 \times 10^{8} \mathrm{~mol} \mathrm{yr}^{-1}$ under totally ice-free conditions, assuming equal AQYs of POM- and DOM-based photoammonification, as is generally the case for CO (Xie and Zafiriou, 2009; G. Song et al., unpublished data, 2012).

\subsection{Biogeochemical implications}

The biogeochemical ramifications of photoammonification can be evaluated by comparision with other major nitrogen fluxes in the SE Beaufort Sea. The Mackenzie River annually supplies $2.2 \times 10^{9}$ moles of DON, $1.9 \times 10^{9}$ moles of DIN (Holmes et al., 2011), and $1.0 \times 10^{5}$ moles of $\mathrm{NH}_{4}^{+}(\mathrm{Mc}-$ Clelland et al., 2008) to the Beaufort Sea. A yearly $\mathrm{NH}_{4}^{+}$ production of $1.4 \times 10^{8}$ moles, therefore, provides a DIN source equivalent to $7 \%$ of the riverine DIN input and 1400 times the riverine $\mathrm{NH}_{4}^{+}$discharge. A yearly $\mathrm{NH}_{4}^{+}$production of $2.1 \times 10^{8}$ moles for the completely ice-free situation would raise these quantities correspondingly to $11 \%$ and 2100 times under otherwise identical conditions. Assuming $80 \%$ of $a_{\text {cdom }}$ on the shelf and $50 \%$ of $a_{\text {cdom }}$ in the basin to be of terrestrial origin (Bélanger et al., 2006), we estimated that photoammonification in the study area could mineralize $4 \%\left(8.8 \times 10^{7}\right.$ moles yr $\left.^{-1}\right)$ and $6 \%\left(1.3 \times 10^{8}\right.$ moles yr $\left.^{-1}\right)$ of the annual riverine DON discharge under the actual icecover and totally ice-free scenario, respectively. Regarding the role of photoammonification as a DIN source, more important than the numeric values is the timing of this process. As discussed in Sect. 3.4, $85 \%$ of the annual $\mathrm{NH}_{4}^{+}$photoproduction took place between June and August, over which the Mackenzie River only delivers $30 \%$ of its annual DIN (mainly nitrate) flux (Emmerton et al., 2008; Holmes et al., 2011). Nitrogen is the limiting element for the growth of heterotrophic prokaryotes on the Mackenzie Shelf in summer (Ortega-Retuerta et al., 2012). Riverine DIN can thus be essentially used up on the shelf before being exported offshore. Ecosystem modeling has, however, demonstrated that currently recognized DIN sources are short of supporting offshore primary productivity observed in the MALINA sampling season (August) (V. Lefouest, unpublished data, 2012). A missing DIN source of $6.0 \mu \mathrm{mol} \mathrm{m}^{-2} \mathrm{~d}^{-1}$, which accounts for $25 \%$ of total DIN uptake in the top 10-m layer, is required to fill the gap. This missing nitrogen is comparable in magnitude to the August $\mathrm{NH}_{4}^{+}$photoproduction rate $\left(8.0 \mu \mathrm{mol} \mathrm{m}^{-2} \mathrm{~d}^{-1}\right)$ obtained from the present study (Table 3). Hence, photoammonification probably drives a previously unrecognized primary production pathway that is at least partly responsible for the continued decline of soluble reactive phosphorus after nitrate is depleted in the upper SE Beaufort Sea following the spring phytoplankton bloom (Tremblay et al., 2008). Notably, heterotrophic prokaryotes compete with primary producers for photochemically formed $\mathrm{NH}_{4}^{+}$, since heterotrophic prokaryotic activity in the offshore Beaufort Sea surface water is also nitrogen-limited in sum- mertime (Ortega-Retuerta et al., 2012). The relative importance of these two $\mathrm{NH}_{4}^{+}$uptake pathways remains to be elucidated.

\subsection{Stoichiometry of DOM photooxidation}

In addition to $\Phi_{\mathrm{NH}_{4}^{+}}$, AQYs of $\mathrm{CO}\left(\Phi_{\mathrm{CO}}\right)$ and $\mathrm{CO}_{2}\left(\Phi_{\mathrm{CO}_{2}}\right)$ were concomitantly determinated (G. Song et al., unpublished data, 2012). Methods for $\Phi_{\mathrm{CO}}$ and $\Phi_{\mathrm{CO}_{2}}$ determinations can be found in the studies by Bélanger et al. (2006), Zhang et al. (2006), and Xie et al. (2009). Such concurrent measurements made it feasible to explore the stoichiometry among the three photoproducts, i.e. the molar ratio of $\mathrm{CO}_{2}: \mathrm{CO}: \mathrm{NH}_{4}^{+}\left(R_{h v}\right)$. $R_{h v}$ was, however, wavelengthdependent, since the shape of AQY vs. wavelength differed among the three species (data not shown). To minimize the varibility of $R_{h v}$, we derived a solar spectrum-weighted mean AQY ( $\bar{\Phi})$ using Eq. (5) (Zhang et al., 2006):

$$
\bar{\Phi}=\frac{\int_{\lambda_{1}}^{\lambda_{2}} Q_{\lambda} \times \Phi_{\lambda} \times d \lambda}{\int_{290}^{600} Q_{\lambda} \times d \lambda} .
$$

$Q_{\lambda}$ is defined in Sect. 3.3. The wavelength range of integration for the numerator is denoted by $\lambda_{1}$ and $\lambda_{2}$, being 290-500 nm for $\mathrm{NH}_{4}^{+}$, and 290-600 nm for $\mathrm{CO}_{2}$ and $\mathrm{CO}$ (Bélanger et al., 2006; Xie et al., 2009). This normalization reduced the AQY spectrum to a single value corresponding to the solar insolation-normalized production of a compound in the entire water column in which all solar radiation over 280$600 \mathrm{~nm}$ was absorbed by CDOM. The calculated $\bar{\Phi}$ and $R_{h v}$ are shown in Table 4. Both the $\mathrm{CO}_{2}: \mathrm{NH}_{4}^{+}$and $\mathrm{CO}: \mathrm{NH}_{4}^{+}$ratios decreased from nearshore to offshore and increased exponentially with $a_{\mathrm{cdom}, 412}$ (Fig. 10) due to the opposing trend between the AQYs of $\mathrm{CO}_{2}$ and $\mathrm{CO}$ and that of $\mathrm{NH}_{4}^{+}$with respect to $a_{\text {cdom. }} R_{h v}$ changed from $165: 11: 1$ in the estuary (Sta. $398,694,697)$ to $60: 3: 1$ on the shelf (Sta. 391, $394,691,693$ ) and 18:2:1 in the basin (Sta. 430, 640). This $R_{h v}$ pattern suggests differing mechanims of and/or environmental control on $\mathrm{CO}_{2}, \mathrm{CO}$, and $\mathrm{NH}_{4}^{+}$photoproduction. Because the DOC:DON ratios for these stations fell into a relatively narrow range of 26 to 37 (Fig. 10), DOM phototransformation tended to enrich its nitrogen proportion in neashore waters but to diminish it in offshore waters. Finally, as a reference to Sect. 3.3, $\bar{\Phi}_{\mathrm{NH}_{4}^{+}}$for Group 2 stations $\left.\left(5.2 \times 10^{-7} \pm 0.4 \times 10^{-7} \mathrm{~mol} \mathrm{NH}_{4}^{+} \text {(mol quanta) }\right)^{-1}\right)$ differed from Group 1 stations $\left(2.4 \times 10^{-7} \pm 0.8 \times 10^{-7} \mathrm{~mol} \mathrm{NH}_{4}^{+}\right.$ (mol quanta) $)^{-1}$ ) by the same factor (i.e. 2) as that based on $\Phi_{\mathrm{NH}_{4}^{+}, 330}$, further underscoring the validity of the SR-based grouping of stations adopted in Sect. 3.1. 
Table 4. Comparision of $\bar{\Phi}$ among $\mathrm{NH}_{4}^{+}, \mathrm{CO}_{2}$ and $\mathrm{CO} . \bar{\Phi}$ is defined in Eq. (5) in the text. $R_{h v}$ is the molar ratio of $\mathrm{CO}_{2}: \mathrm{CO}: \mathrm{NH}_{4}^{+}$and equal to $\bar{\Phi}_{\mathrm{CO}_{2}}: \bar{\Phi}_{\mathrm{CO}}: \bar{\Phi}_{\mathrm{NH}_{4}^{+}}$. n.d. = not determined.

\begin{tabular}{|c|c|c|c|c|c|}
\hline \multirow[t]{2}{*}{ Location } & \multirow[t]{2}{*}{ Station } & \multicolumn{3}{|c|}{$\bar{\Phi} \times 10^{7}$} & \multirow[t]{2}{*}{$R_{h v}$} \\
\hline & & $\mathrm{CO}_{2}$ & $\mathrm{CO}$ & $\mathrm{NH}_{4}^{+}$ & \\
\hline \multirow{3}{*}{ Transect 390} & 391 & 270 & $9.1^{\mathrm{a}}$ & 5.4 & $60: 2: 1$ \\
\hline & 394 & 136 & 11 & 3.0 & $42: 4: 1$ \\
\hline & 398 & 288 & $13^{\mathrm{b}}$ & 2.9 & $88: 4: 1$ \\
\hline \multirow{4}{*}{ Transect 690} & 691 & 207 & 9.1 & 5.0 & $46: 2: 1$ \\
\hline & 693 & 187 & 13 & 2.9 & $56: 4: 1$ \\
\hline & 694 & 222 & 20 & 2.3 & $99: 9: 1$ \\
\hline & 697 & 253 & 22 & 1.1 & $230: 19: 1$ \\
\hline \multirow{2}{*}{ Offshore } & 430 & n.d. & 17 & 5.3 & $3: 1^{\mathrm{c}}$ \\
\hline & 640 & 83 & 8.9 & 5.3 & $18: 2: 1$ \\
\hline
\end{tabular}

a No data are avaiable for CO at Sta. 391. Data shown are from Sta. 392, whose salinity (27.90) and $a_{\text {cdom, } 412}\left(0.10 \mathrm{~m}^{-1}\right)$ values are similar to those of Sta. 391 $\left(27.82,0.11 \mathrm{~m}^{-1}\right)$.

${ }^{b}$ No data are avaiable for $\mathrm{CO}_{2}$ and $\mathrm{CO}$ at Sta. 398. Data shown are from Sta. 396, whose salinity (17.27) and $a_{\mathrm{cdom}, 412}\left(1.04 \mathrm{~m}^{-1}\right)$ values are similar to those of Sta. $398\left(16.37,1.15 \mathrm{~m}^{-1}\right)$.

${ }^{\mathrm{c}}$ Molar ratio of $\mathrm{CO}: \mathrm{NH}_{4}^{+}$only.

\section{Conclusions}

Photoammonification was detected in all samples collected from both nearshore and offshore warters of the SE Beaufort Sea. The rate of photoammonification was positively correlated to CDOM absorbance and DON concentration. On an absorbed-photon basis, photoammonification, however, was inversely related to CDOM absorbance, leading to $\Phi_{\mathrm{NH}_{4}^{+}}$increasing seaward. The UVA (320-400 nm) component of the solar spectrum dominated photoammonification at the sea surface. The photochemical ratio of $\mathrm{CO}_{2}: \mathrm{CO}: \mathrm{NH}_{4}^{+}$varied from $165: 11: 1$ in the estuary to $60: 3: 1$ on the shelf and $18: 2: 1$ in the basin, indicating a greater photoreactivity of terrestrial DOM with respect to $\mathrm{CO}_{2}$ and $\mathrm{CO}$ than to $\mathrm{NH}_{4}^{+}$. Coupled optical-photochemical modeling yielded photoammonification rates of $7.3 \mathrm{nmoll}^{-1} \mathrm{~d}^{-1}$ (Mackenzie Shelf) and $3.5 \mathrm{nmol}^{-1} \mathrm{~d}^{-1}$ (Canada Basin) at the sea surface and $9.2 \mu \mathrm{mol} \mathrm{m}{ }^{-2} \mathrm{~d}^{-1}$ (Mackenzie Shelf) and $10.8 \mu \mathrm{mol} \mathrm{m}{ }^{-2} \mathrm{~d}^{-1}$ (Canada Basin) in the entire water column. The modeled offshore $\mathrm{NH}_{4}^{+}$photoproduction in August $\left(8.0 \mu \mathrm{mol} \mathrm{m}{ }^{-2} \mathrm{~d}^{-1}\right)$ was comparable to the missing DIN source that supported primary production in the upper $10-\mathrm{m}$ layer after nitrate depletion. Annual $\mathrm{NH}_{4}^{+}$photoproduction in the SE Beaufort Sea in 2009 amounted to $1.4 \times 10^{8}$ moles, of which $85 \%$ was formed in the summer season when nitrate is usually depleted. Photoammonification under a completely icefree scenario, generating $2.1 \times 10^{8}$ moles of $\mathrm{NH}_{4}^{+}$per year, could mineralize $6 \%$ of the annual DON transported from the Mackenzie River and provide a DIN source representing $11 \%$ of the riverine DIN export and 2100 times the riverine

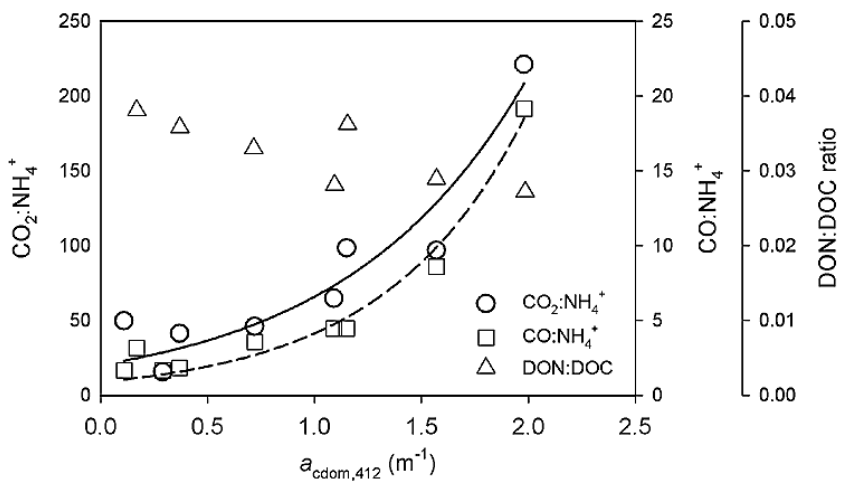

Fig. 10. Plots of photochemical molar ratios of $\mathrm{CO}_{2}$ to $\mathrm{NH}_{4}^{+}$and $\mathrm{CO}$ to $\mathrm{NH}_{4}^{+}$vs. $\mathrm{CDOM}$ absorption coefficient at $412 \mathrm{~nm}$. Data were fitted to the equation of $Y=20.4 \exp (1.17 X)$ for $\mathrm{CO}_{2}: \mathrm{NH}_{4}^{+}$(solid line; $\left.r^{2}=0.908, n=8\right)$ and $Y=0.90 \exp (1.53 X)$ for $\mathrm{CO}: \mathrm{NH}_{4}^{+}$ (dashed line; $r^{2}=0.968, n=9$ ). Superimposed is the plot of DON : DOC ratio vs. CDOM absorption coefficient.

$\mathrm{NH}_{4}^{+}$discharge. This light-initiated process thus plays a significant role in nitrogen cycling and biological production in the SE Beaufort Sea.

Future studies should resolve potential seasonality of $\Phi_{\mathrm{NH}_{4}^{+}}$and increase sampling resolutions, especially in offshore waters. A quantitative assessment of the temperature dependence of photoammonification is particularly relevant to this climatically sensitive region. Rising surface water temperatures can directly increase the efficiency of photoammonification (Sect. 3.3), which would support additional primary production and perhaps lead to more riverine photoammonificable DON being used closer to the shore.

\section{Supplementary material related to this article is available online at: http://www.biogeosciences.net/9/ 3047/2012/bg-9-3047-2012-supplement.pdf.}

Acknowledgements. R. M. Holmes helped with collecting the Mackenzie River water sample near Inuvik. Y. Zhang assisted in the preparation of Fig. 1. We thank the captain, crew, and colleagues of the CCGS Amundsen cruise for their cooperation. Reviewers' suggestions improved the manuscript. This study was supported by grants from the Natural Sciences and Engineering Research Council (NSERC) to HX and SB and the National Science Foundation (NSF 0713915) to RB. It was conducted as part of the Malina Scientific Program funded by ANR (Agence nationale de la recherche), INSU-CNRS (Institut national des sciences de l'univers - Centre national de la recherche scientifique), CNES (Centre national d'études spatiales) and ESA (European Space Agency).

Edited by: E. Boss 


\section{References}

Aarnos, H., Ylöstalo, P., and Vähätalo, A. V.: Seasonal phototransformation of dissolved organic matter to ammonium, dissolved inorganic carbon, and labile substrates supporting bacterial biomass across the Baltic Sea, J. Geophys. Res., 117, G01004, doi:10.1029/2010JG001633, 2012.

Amon, R. M. W.: The role of dissolved organic matter for the organic carbon cycle in the Arctic Ocean, in: The Organic Carbon Cycle in the Arctic Ocean, edited by: Stein, R. and MacDonald, R. W., Springer, New York, 83-99, 2004.

Babin, M., Stramski, D., Ferrari, G. M., Claustre, H., Bricaud, A., Obolensky, G., and Hoepffner, N.: Variations in the light absorption coefficients of phytoplankton, nonalgal particles, and dissolved organic matter in coastal waters around Europe, J. Geophys. Res., 108, 3211, doi:10.1029/2001JC000882, 2003.

Bélanger, S.: Response of light-related carbon fluxes in the Arctic Ocean to climate change: Quantification and monitoring of dissolved organic matter photo-oxidation in the Beaufort Sea using satellite remote sensing, Ph.D. thesis, Université Pierre et Marie Curie (UPMC - Paris XI), Paris, France, 2006.

Bélanger, S., Xie, H., Krotkov, N., Larouche, P., Vincent, W. F., and Babin, M.: Photomineralization of terrigenous dissolved organic matter in Arctic coastal waters from 1979 to 2003: Interannual variability and implications of climate change, Global Biogeochem. Cy., 20, GB4005, doi:10.1029/2006GB002708, 2006.

Bélanger, S., Babin, M., and Larouche, P.: An empirical ocean color algorithm for estimating the contribution of chromophoric dissolved organic matter to total light absorption in optically complex waters, J. Geophys. Res. 113, C04027, doi:10.1029/2007JC004436, 2008.

Benner, R. and Kaiser, K.: Biological and photochemical transformations of lignin phenols and amino acids in riverine dissolved organic matter, Biogeochemistry, 102, 209-222, 2011.

Bertilsson, S., Stepanauskas, R., Cuadros-Hansson, R., Granéli, W., Wikner, J., and Tranvik, L.: Photochemically induced changes in bioavailable carbon and nitrogen pools in a boreal watershed, Aquat. Microb. Ecol., 19, 47-56, 1999.

Buffam, I. and McGlathery, K. J.: Effect of ultraviolet light on dissolved nitrogen transformations in coastal lagoon water, Limnol. Oceanogr., 48, 723-734, 2003.

Buiteveld, H., Hakvoort, J. M. H., and Donze, M.: The optical properties of pure water, in: SPIE Proceedings on Ocean Optics XII, edited by: Jaffe, J. S., The Society of Photo-Optical Instrumentation Engineers, Bellingham, Washington, USA, 174-183, 1994.

Bushaw, K. L., Zepp, R. G., Tarr, M. A., Schultz-Jander, D., Bourbonniere, R. A., Hodson, R. E., Miller, W. L., Bronk, D. A., and Moran, M. A.: Photochemical release of biologically available nitrogen from aquatic dissolved organic matter, Nature, 381, 404-407, 1996.

Davis, J. and Benner, R.: Seasonal trends in the abundance, composition and bioavailability of particulate and dissolved organic matter in the Chukchi/Beaufort Seas and western Canada Basin, Deep-Sea Res. Pt. II, 52, 3396-3410, 2005.

Dittmar, T. and Kattner, G.: The biogeochemistry of the river and shelf ecosystem of the Arctic Ocean: a review, Mar. Chem., 83, 105-120, 2003.

Emmerton, C. A., Lesack, L. F. W., and Vincent. W. F.: Mackenzie River nutrient delivery to the Arctic Ocean and effects of the Mackenzie Delta during open water conditions, Global Bio- geochem. Cy., 22, GB1024, doi:10.1029/2006GB002856, 2008.

Gao, H. and Zepp, R. G.: Factors influencing photoreactions of dissolved organic matter in a coastal river of the Southeastern United States, Environ. Sci. Technol., 32, 2940-2946, 1998.

Gordon, H. R.: Can the Lambert-Beer law be applied to the diffuse attenuation coefficient of ocean water, Limnol. Oceanogr., 34, 1389-1409, 1989.

Grasshoff, K., Kremling, K., and Ehrhardt, M.: Methods of Seawater Analysis, Wiley-VCHVerlag GmbH, Weinheim, Germany, 1999.

Gueymard, C.: Parameterized transmittance model for direct beam and circumsolar spectral irradiance, Sol. Energy, 71, 325-346, 2001.

Helms, J. R., Stubbins, A., Ritchie, J. D., Minor,E. C., Kieber, D. J., and Mopper, K.: Absorption spectral slopes and slope ratios as indicators of molecular weight, source, and photobleaching of chromophoric dissolved organic matter, Limnol. Oceanogr., 53, 955-969, 2008.

Holmes, R. M., Aminot, A., Keìrouel, R., Hooker, B. A., and Peterson, B. J.: A simple and precise method for measuring ammonium in marine and freshwater ecosystems, Can. J. Fish. Aquat. Sci., 56, 1801-1808, 1999.

Holmes, R. M., McClelland, J. W., Peterson, B. J., Tank, S. E., Bulygina, E., Eglinton, T. I., Gordeev, V. V., Gurtovaya, T. Y., Raymond, P. A., Repeta, D. J., Staples, R., Striegl, R. G., Zhulidov, A. V., and Zimov, S. A.: Seasonal and annual fluxes of nutrients and organic matter from large rivers to the Arctic Ocean and surrounding seas, Estuar. Coast., 35, 369-382, doi:10.1007/s12237011-9386-6, 2011.

Hu, C., Muller-Karger, F. E., and Zepp, R. G.: Absorbance, absorption coefficient, and apparent quantum yield: A comment on common ambiguity in the use of these optical concepts, Limnol. Oceanogr., 47, 1261-1267, 2002.

IOCCG: Remote sensing of inherent optical properties: Fundamentals, tests of algorithms, and applications, in: Reports of the International Ocean-Colour Coordinating Group, No. 5, edited by: Lee, Z.-P., IOCCG, Dartmouth, Canada, 2006.

Johannessen, S. C. and Miller, W. L.: Quantum yield for the photochemical production of dissolved inorganic carbon in seawater, Mar. Chem., 76, 271-283, 2001.

Jørgensen, N. O. G., Tranvik, L., Edling, H., Graneli, W., and Lindell, M.: Effects of sunlight on occurrence and bacterial turnover of specific carbon and nitrogen compounds in lake water, FEMS Microbiol. Ecol., 25, 217-227, 1998.

Kieber, R. J., Hydro, L. H., and Seaton, P. J.: Photooxidation of triglycerides and fatty acids in seawater: Implication toward the formation of marine humic substances, Limnol. Oceanogr., 42, 1454-1462, 1997.

Kitidis, V., Uher, G., Upstill-Goddard, R. C., Mantoura, R. F. C., Spyres, G., and Woodward, E. M. S.: Photochemical production of ammonium in the oligotrophic Cyprus Gyre (Eastern Mediterranean), Biogeosciences, 3, 439-449, doi:10.5194/bg-3439-2006, 2006.

Kitidis, V., Uher, G., Woodward, E. M. S., Owens, N. J. P., and Upstill-Goddard, R. C.: Photochemical production and consumption of ammonium in a temperate river-sea system, Mar. Chem., 112, 118-127, 2008.

Koopmans, D. J. and Bronk, D. A.: Photochemical production of dissolved inorganic nitrogen and primary amines from dissolved 
organic nitrogen in waters of two estuaries and adjacent surficial groundwaters, Aquat. Microb. Ecol., 26, 295-304, 2002.

Lee, Z.-P., Carder, K. L., and Arnone, R. A.: Deriving inherent optical properties from water color : a multiband quasi-analytical algorithm for optically deep waters, Appl. Opt., 41, 5755-5772, 2002.

Matsuoka, A., Bricaud, A., Benner, R., Para, J., Sempéré, R., Prieur, L., Bélanger, S., and Babin, M.: Tracing the transport of colored dissolved organic matter in water masses of the Southern Beaufort Sea: relationship with hydrographic characteristics, Biogeosciences, 9, 925-940, doi:10.5194/bg-9-925-2012, 2012.

Mayer, L. M., Schick, L. L., Hardy, K. R, and Estapa, M. L.: Photodissolution and other photochemical changes upon irradiation of algal detritus, Limnol. Oceanogr., 54, 1688-1698, 2009.

McClelland, J. W., Holmes, R. M., Peterson, B. J., Amon, R. M. W., Brabets, T., Cooper, L., Gibson, J., Gordeev, V. V., Guay, C., Milburn, D., Staples, R., Raymond, P. A., Shiklomanov, I., Striegl, R., Zhulidov, A., Gurtovaya, T., and Zimov, S.:, Development of a Pan-Arctic database for river chemistry, Eos Trans. AGU, 89, 217, doi:10.1029/2008EO240001, 2008.

Mopper, K. and Kieber, J. K.: Photochemistry and the cycling of carbon, sulfur, nitrogen and phosphorus, in: Biogeochemistry of Marine Dissolved Organic Matter, edited by: Hansell, D. A. and Carlson, C. A., Academic Press, 455-489, 2002.

Ortega-Retuerta, E., Jeffrey, W. H., Ghiglione, J. F., and Joux, F.: Evidence of heterotrophic prokaryotic activity limitation by nitrogen in the Western Arctic Ocean during summer, Polar Biol., 35, 785-794, 2012.

Osburn, C. L., Retamal, L., and Vincent, W. F.: Photoreactivity of chromophoric dissolved organic matter transported by the Mackenzie River to the Beaufort Sea, Mar. Chem., 115, 10-20, 2009.

Pope, R. M. and Fry, E. S.: Absorption spectrum (380-700 nm) of pure water, II: Integrating cavity measurements, Appl. Optics, 36, 8710-8723, 1997.

Ricchiazzi, P., Yang, S., Gautier, C., and Sowle, D.: SBDART: A research and teaching software tool for plane-parallel radiative transfer in the earth's atmosphere, B. Am. Meteorol. Soc., 79, 2101-2114, 1998.

Simpson, K. G., Tremblay, J.-É., Gratton, Y., and Price, N. M.: An annual study of inorganic and organic nitrogen and phosphorus and silicic acid in the southeastern Beaufort Sea, J. Geophys. Res., 113, C07016, doi:10.1029/2007JC004462, 2008.

Smith, E. M. and Benner, R.: Photochemical transformations of riverine dissolved organic matter: effects on estuarinebacterial metabolism and nutrient demand, Aquat. Microb. Ecol., 40, 3750, 2005.

Stedmon, C. A., Markager, S., Tranvik, L., Kronberg, L., Slätis, T., and Martinsen, W.: Photochemical production of ammonium and transformation of dissolved organic matter in the Baltic Sea, Mar. Chem., 104, 227-240, 2007.

Stubbins, A., Uher, G., Law, C. S., Mopper, K., Robinson, C., and Upstill-Goddard, R. C.: Open-ocean carbon monoxide photoproduction, Deep-Sea Res. Pt. II, 53, 1695-1705, 2006.

Stubbins, A., Law, C. S., Uher, G., and Upstill-Goddard, R. C.: Carbon monoxide apparent quantum yields and photoproduction in the Tyne estuary, Biogeosciences, 8, 703-713, doi:10.5194/bg-8 703-2011, 2011.

Tank, S. E., Manizza, M., Holmes, R. M., McClelland, J. W., and Peterson, B. J.: The Processing and impact of dissolved riverine nitrogen in the Arctic Ocean, Estuar. Coast., 35, 401-415, doi:10.1007/s12237-011-9417-3, 2011.

Tarr, M. A., Wang, W., Bianchi, T. S., and Engelhaupt, E.: Mechanisms of ammonia and amino acid photoproduction from aquatic humic and colloidal matter, Water Res., 35, 3688-3696, 2001.

Tremblay, J.-É., Simpson, K., Martin, J., Miller, L., Gratton, Y., Barber, D., and Price, N. M.: Vertical stability and the annual dynamics of nutrients and chlorophyll fluorescence in the coastal, southeast Beaufort Sea, J. Geophys. Res., 113, C07S90, doi:10.1029/2007JC004547, 2008.

Vähätalo, A. V. and Zepp, R. G.: Photochemcial mineralisation of dissolved organic nitrogen to ammonium in the Baltic Sea, Environ. Sci. Technol., 39, 6985-6992, 2005.

Vähätalo, A. V., Salonen, K., Münster, U., Jävinen, M., and Wetzel, R. G.: Photochemical transformation of allochthonous organic matter provides bioavailable nutrients in a humic lake, Arch. Hydrobiol., 156, 287-314, 2003.

Wang, W., Tarr, M. A., Bianchi, T. S., and Engelhaupt, E.: Ammonium Photoproduction from Aquatic Humic and Colloidal Matter, Aquatic Geochemistry, 6, 275-292, 2000.

White, E. M., Kieber, D. J., Sherrard, J., Miller, W. L., and Mopper, K.: Carbon dioxide and carbon monoxide photoproduction quantum yields in the Delaware Estuary, Mar. Chem., 118, 1121,2010

Wiegner, T. N. and Seitzinger, S. P.: Photochemical and microbial degradation of external dissolved organic matter inputs to rivers, Aquat. Microb. Ecol., 24, 27-40, 2001.

Xie, H. and Zafiriou, O. C.: Evidence for signi?cant photochemical production of carbon monoxide by particles in coastal and oligotrophic marine waters, Geophys. Res. Lett., 36, L23606, doi:10.1029/2009GL041158, 2009.

Xie, H., Bélanger, S., Demers, S., Vincent, W. F., and Papakyriakou, T. N.: Photobiogeochemical cycling of carbon monoxide in the southeastern Beaufort Sea in spring and autumn, Limnol. Oceanogr., 54, 234-249, 2009.

Zafiriou, O. C., Andrews, S. S., and Wang, W.: Concordant estimates of oceanic carbon monoxide source and sink processes in the Pacific yield a balanced global "blue-water" CO budget, Global Biogeochem. Cy., 17, 1015-1027, 2003.

Zhang, Y., Rossow, W. B., Lacis, A. A., Oinas, V., and Mishchenko, M. I.: Calculation of radiative fluxes from the surface to top of atmosphere based on ISCCP and other global data sets: Refinements of the radiative transfer model and the input data, J. Geophys. Res., 109, D19105, doi:10.1029/2003JD004457, 2004.

Zhang, Y., Xie, H., and Chen, G.: Factors affecting carbon monoxide photoproduction in the St. Lawrence estuarine system (Canada), Environ. Sci. Technol., 40, 771-777, 2006.

Ziolkowski, L. A. and Miller, W. L.: Variability of the apparent quantum efficiency of CO photoproduction in the Gulf of Maine and Northwest Atlantic, Mar. Chem., 105, 258-270, 2007. 